IZA DP No. 6383

Fiscal Zoning, Sales Taxes, and Employment:

Do Higher Sales Taxes Lead to More Jobs in

Retailing and Fewer Jobs in Manufacturing?

Daria Burnes

David Neumark

Michelle J. White

February 2012 


\title{
Fiscal Zoning, Sales Taxes, and Employment: Do Higher Sales Taxes Lead to More Jobs in Retailing and Fewer Jobs in Manufacturing?
}

\author{
Daria Burnes \\ UC Irvine
}

\section{David Neumark}

UC Irvine,

NBER and IZA

\author{
Michelle J. White \\ UC San Diego, \\ CKGSB and NBER
}

\section{Discussion Paper No. 6383 \\ February 2012}

IZA

P.O. Box 7240

53072 Bonn

Germany

\author{
Phone: +49-228-3894-0 \\ Fax: +49-228-3894-180 \\ E-mail: iza@iza.org
}

\begin{abstract}
Any opinions expressed here are those of the author(s) and not those of IZA. Research published in this series may include views on policy, but the institute itself takes no institutional policy positions.

The Institute for the Study of Labor (IZA) in Bonn is a local and virtual international research center and a place of communication between science, politics and business. IZA is an independent nonprofit organization supported by Deutsche Post Foundation. The center is associated with the University of Bonn and offers a stimulating research environment through its international network, workshops and conferences, data service, project support, research visits and doctoral program. IZA engages in (i) original and internationally competitive research in all fields of labor economics, (ii) development of policy concepts, and (iii) dissemination of research results and concepts to the interested public.
\end{abstract}

IZA Discussion Papers often represent preliminary work and are circulated to encourage discussion. Citation of such a paper should account for its provisional character. A revised version may be available directly from the author. 


\section{ABSTRACT}

\section{Fiscal Zoning, Sales Taxes, and Employment: Do Higher Sales Taxes Lead to More Jobs in Retailing and Fewer Jobs in Manufacturing?*}

We test the hypothesis that local government officials in jurisdictions that have higher local sales taxes are more likely to use fiscal zoning to attract retailing. We find that total retail employment is not significantly affected by local sales tax rates, but employment in big box and anchor stores is higher significantly in jurisdictions with higher sales tax rates. This suggests that local officials in jurisdictions with higher sales tax rates concentrate on attracting large stores and shopping centers. We also find that the effect of local sales taxes on big box and anchor store retail employment is larger in county interiors, where residents tend to be captive to local retailers. Finally, fiscal zoning has the opposite effect on manufacturing employment, suggesting that local officials' efforts to attract shopping centers and large stores crowd out manufacturing.

JEL Classification: R3, R5, J2, H2

Keywords: fiscal zoning, sales taxes, retail employment, manufacturing employment

Corresponding author:

David Neumark

Department of Economics

3151 Social Science Plaza

University of California, Irvine

Irvine, CA 92697

USA

E-mail: dneumark@uci.edu

\footnotetext{
* The authors are grateful to the Public Policy Institute of California and the David A. Coulter Family Foundation for support for using the NETS data for this research. We also thank Tony Soeller for assistance with ArcGIS, Eve Irwin for assistance with the Florida population data and institutional detail, Sima Kamouie and Linchun Chen for research assistance, and William Strange, two anonymous reviewers, and seminar participants at $\mathrm{UCl}$, Rice, the University of Houston, the American Law and Economics Association Conference, and the Southern California Conference in Applied Microeconomics. The views expressed are not those of the Public Policy Institute of California. White is grateful to the Cheung Kong Graduate School of Business, Beijing, for hospitality and financial support.
} 


\section{Introduction}

Many U.S. states allow local governments to levy sales taxes that add to the state sales tax and to keep some or all of the revenue (Lewis, 2001). These extra sales taxes give local government officials an incentive to encourage retailing, since retailing generates more sales tax revenue than other land uses. Correspondingly, these taxes also give local government officials an incentive to discourage other land uses, since they generate less sales tax revenue and could crowd out retailing.

Local government officials have various policy instruments and practices that they can use to encourage retailing: they can zone additional land for retail use, they can allow land zoned for retailing to be developed at higher density levels, and they can reduce the often-formidable set of approvals and inspections that are required for construction or renovation. They can use all of these instruments and practices in reverse to discourage other land uses. We use the term "fiscal zoning" to refer to local government officials' efforts to encourage land uses that generate high tax revenue — which in this case we interpret as high sales tax revenue. In this paper, we first develop a model of fiscal zoning that predicts that local government officials are more likely to use fiscal zoning to encourage retailing when the sales tax rate in their jurisdiction is higher. We then test this prediction empirically by examining whether retail employment increases in response to higher sales tax rates.

Manufacturing may compete with large stores and shopping centers for land, because both occupy large tracts of flat land close to highways. In addition, manufacturing generates less sales tax revenue than retailing, because sales taxes are levied only on final sales to consumers and manufacturers rarely sell to final consumers. ${ }^{1}$ As a result, if local officials favor retailing in order to increase sales tax revenue, the level of manufacturing activity and the number of manufacturing jobs may fall. We therefore also examine whether manufacturing employment falls in jurisdictions where local sales tax rates increase.

We have three main findings. First, total retail employment is not significantly affected by variation in local sales tax rates. This may be because local government officials do not use fiscal zoning,

\footnotetext{
${ }^{1}$ States make some exceptions to the rule that sales taxes are levied only on final sales. But see Hawkins and Murray (2004) for evidence that manufacturing generates little or no additional local sales tax revenue.
} 
but it alternately may occur because the positive effect of fiscal zoning on retail employment is fully offset by the dampening effect of higher sales tax rates on consumer demand. ${ }^{2}$ Second, and more consistent with the fiscal zoning hypothesis, we find that higher local sales tax rates lead to more employment in "big box" stores and in department stores that anchor shopping malls. This result suggests that local officials concentrate their fiscal zoning efforts on attracting large stores and shopping malls and that they compete more heavily for these when local sales tax rates are higher. The fiscal zoning effect on big box and anchor stores may arise because these stores generate particularly high sales tax revenue or because they are particularly sensitive to local officials' efforts to attract them. And third, increases in sales tax rates lead to lower employment in manufacturing, suggesting that local officials' efforts to attract big box stores and shopping centers crowd out manufacturing.

\section{Literature Review}

The hypothesis that local government officials use zoning to choose land uses based on the relationship between local tax payments associated with these uses and the cost of providing the necessary local public goods to support them was first proposed by Hamilton (1975) as an extension to the Tiebout Model (1952). In Hamilton's model, the main source of local government revenue is the property tax, and local governments use zoning to prevent land uses from being developed if they would cost the local government more than they would generate in property tax payments. As a result, the property tax becomes a benefit tax. White (1975) and Ohls et al. (1974) extended the model by assuming that local government officials use zoning to select land uses that maximize the local government's tax revenue net of $\operatorname{costs}^{3}{ }^{3}$ The latter model implies that local government officials typically prefer singlefamily houses over apartments, because single-family houses generate higher property tax payments, and prefer commercial and industrial land uses over housing since non-residential land uses do not raise local

\footnotetext{
${ }^{2}$ See Mark et al. (2000) for an analysis of the effects of sales taxes and other taxes on economic activity within a single metropolitan area.

${ }^{3}$ See Fischel (1992) for discussion. Other models of profit-maximizing communities include Sonstelie and Portney (1978) and Epple and Zelenitz (1981), but neither explicitly considers zoning. See Gordon and Li (2012) for a recent application of the fiscal zoning model to behavior of local governments in China.
} 
governments' costs by increasing enrollment in public schools. ${ }^{4}$

More recently, political scientists have examined local officials' use of zoning to encourage land uses that generate high tax revenues, but with a focus on local sales taxes rather than property taxes. They argue that local officials use zoning to encourage retailing at the expense of other land uses, because retailing brings in the most sales tax revenue. These studies often use California as their setting, since property tax revenues in California have fallen sharply since the late 1970's and local governments there are allowed to adopt local sales taxes. One such study is by Lewis and Barbour (1999), who surveyed city managers in California to determine what types of development they favor and why. They concluded that city managers strongly favor retailing and do so because it generates additional sales tax revenue. But Lewis and Barbour's study failed to examine whether local officials are more likely to use zoning to attract retail activity when sales tax rates are higher, nor did it examine whether officials' efforts were successful. ${ }^{5}$ Our paper provides a theoretical model of fiscal zoning under sales taxes and tests it empirically.

\section{Theoretical Model}

Assume that local government officials use their zoning power to determine the types of development that occur within their jurisdictions. They do so by assigning tracts of open space to zoning categories that include retailing, manufacturing, office buildings, housing, and others. Although local officials have multiple tools at their disposal for controlling development, in the model we focus on zoning exclusively. Suppose $Z_{r}$ denotes the number of acres zoned for retail use in jurisdiction $j$ and $Z_{m}$ denotes the number of acres zoned for manufacturing use in jurisdiction $j$. When local officials in jurisdiction $j$ zone additional land for retail use, they may compensate by zoning less land for manufacturing use, less land for any other use, or they may leave less land vacant in the jurisdiction. Similarly, when they zone additional land for manufacturing, they may zone less land for retail use, less

\footnotetext{
${ }^{4}$ Commercial and industrial land uses may of course be undesirable if they generate high pollution or congestion. ${ }^{5}$ Studies by political scientists tend to ignore the issue of whether different types of development generate different costs of supplying local public goods - presumably because non-residential land uses generate similar cost levels. For other discussions by political scientists of fiscal zoning and competition for retailing, see Misczynski (1986), Fulton (1998), and Schrag (1998).
} 
land for any other use, or they may leave less land vacant. We assume that land zoned for retailing and land zoned for manufacturing may be substitutes, so that an additional acre zoned for retailing results in a reduction of up to one acre in the amount of land zoned for manufacturing, or $-1 \leq \partial Z_{r} / \partial Z_{m} \leq 0$. In the two extreme cases, an additional acre of land zoned for retailing means one acre less land zoned for manufacturing, or no effect on the number of acres zoned for manufacturing. ${ }^{6}$

The value of land zoned for retail use and manufacturing use in jurisdiction $j$ is denoted $V_{r}$ and $V_{m}$ per acre, respectively. $V_{r}$ depends negatively on the total amount of land zoned for retail use in jurisdiction $j, Z_{r}$, and, because of capitalization of taxes into land values, $V_{r}$ also depends negatively on the sales and property tax rates in jurisdiction $j$, denoted $\sigma$ and $\pi$. Also, because sites in neighboring counties are substitutable, $V_{r}$ depends positively on the sales tax rate in neighboring jurisdictions, denoted $\tau .^{7} V_{m}$ depends negatively on the total amount of land zoned for manufacturing and on the property tax rate in jurisdiction $j, \pi$. The value of retail sales per acre in jurisdiction $j$ is denoted $S$, where $S$ could depend either positively or negatively on the amount of land zoned for retailing $Z_{r}$. The relationship between $S$ and $Z_{r}$ is likely to be negative because additional stores compete with each other for sales, but could be positive if additional stores increase shopping agglomeration economies. Because taxes are passed on to consumers in part as retail price increases, $S$ also depends negatively on the sales and property tax rates in jurisdiction $j, \sigma$ and $\pi$, and positively on the sales tax rate in neighboring jurisdictions, $\tau$. $S$ may also have a random component to reflect the fact that stores and shopping centers may be successful or unsuccessful. The cost of providing local public goods per acre devoted to new retail and manufacturing uses are denoted $G_{r}$ and $G_{m}$, respectively.

Local officials are assumed to choose how much land to zone for retail and manufacturing use so as to maximize the net tax revenues $(N T R)$ generated by new development, or:

$$
N T R=\sigma \cdot S\left(Z_{r}, \sigma, \pi, \tau\right) Z_{r}+\pi \cdot V_{r}\left(Z_{r}, \sigma, \pi, \tau\right) Z_{r}+\pi \cdot V_{m}\left(Z_{m}, \pi\right) Z_{m}-G_{r} Z_{r}-G_{m} Z_{m}
$$

\footnotetext{
${ }^{6} \mathrm{We}$ assume that zoned land is developed quickly. In actuality, local officials sometimes zone land for particular uses knowing that it will remain undeveloped. The model ignores this type of zoning. We also ignore rezoning of already developed land. When developed land is rezoned, it is allowed to remain in the old use ("grandfathered"), subject to some limitations.

${ }^{7}$ We simplify by assuming there is only one neighboring tax rate.
} 
The first and second terms in (1) are the local sales tax and property tax paid by newly developed retail stores, while the third term is property taxes paid by newly-developed manufacturing firms. The fourth and fifth terms are the cost of supplying local public goods to newly-developed retail stores and manufacturing firms.

Local government officials choose $Z_{r}$ and $Z_{m}$ so as to maximize $N T R{ }^{8}$ Assuming an interior maximum, the first-order condition for the amount of land zoned for retailing is:

$$
\sigma \cdot S\left[\varepsilon_{S, Z_{r}}+1\right]+\pi \cdot V_{r}\left[\varepsilon_{V_{r}, Z_{r}}+1\right]+\pi \cdot V_{m}\left[\varepsilon_{V_{m}, Z_{m}}+1\right] \frac{\partial Z_{m}}{\partial Z_{r}}-G_{r}-G_{m} \frac{\partial Z_{m}}{\partial Z_{r}}=0
$$

The first term in (2) is the increase in sales tax revenue that occurs when jurisdiction $j$ zones more land for retailing and therefore increases the number of stores in jurisdiction $j$. This term will be positive as long as the elasticity of retail sales per acre with respect to the amount of land zoned for retailing, $\varepsilon_{S, Z_{r}}$, exceeds -1 (that is, as long as sales per acre do not decline too sharply in response to zoning more land for retail use). The second term is the change in property tax revenues from zoning more land for retailing. This term is positive as long as the elasticity of the value of retail land per acre with respect to the amount of land zoned for retailing, $\varepsilon_{V_{r}, Z_{r}}$, exceeds -1 (that is, as long as the value of retail land does not decline too sharply when more land is zoned for retail use).

The third term is the indirect effect of zoning more land for retail use, because less land is zoned for manufacturing use and therefore property tax revenues from manufacturing fall. It is negative as long as $\partial Z_{m} / \partial Z_{r}$ is negative (there is some tradeoff between these two land uses) and the elasticity of the value of manufacturing land per acre with respect to the amount of land zoned for manufacturing, $\varepsilon_{V_{m}, Z_{m}}$, is greater than -1 (that is, as long as the value of land zoned for manufacturing does not decline too sharply when more land is zoned for manufacturing). Finally, the fourth and fifth terms measure the effect of zoning more land for retail use on the cost of supplying local public goods and services to retailing and

\footnotetext{
${ }^{8}$ We ignore strategic interactions between local governments, and treat policy in other jurisdictions as captured in $\tau$; we defined $\tau$ to be the neighboring jurisdiction's sales tax rate, but we could also introduce a property tax in neighboring jurisdictions without changing the results. Although officials may care about net tax revenues per capita, we treat population as fixed rather than modeling population responses to policy changes.
} 
manufacturing uses. The fourth term must be negative since costs rise when more land is zoned for retail use, while the fifth term is the indirect effect on costs of supplying local public goods to land zoned for manufacturing — which is likely to be small.

Next, consider the first-order condition for zoning additional land for manufacturing, which is:

$$
\sigma \cdot S\left[\varepsilon_{S, Z_{r}}+1\right] \frac{\partial Z_{r}}{\partial Z_{m}}+\pi \cdot V_{r}\left[\varepsilon_{V_{r}, Z_{r}}+1\right] \frac{\partial Z_{r}}{\partial Z_{m}}+\pi \cdot V_{m}\left[\varepsilon_{V_{m}, Z_{m}}+1\right]-G_{r} \frac{\partial Z_{r}}{\partial Z_{m}}-G_{m}=0 .
$$

Each term in condition (3) has the same interpretation as the analogous term in (2), except that direct effects in one expression become indirect effects in the other, and vice versa. As long as $\partial Z_{r} / \partial Z_{m}$ is negative, all of the terms in (3) have the opposite signs as the analogous terms in (2). In particular, the first term is negative, so that more land zoned for manufacturing reduces sales tax revenue.

Now consider how an increase in the local sales tax rate affects jurisdiction $j$ 's gain from zoning additional land for retailing versus manufacturing, which is central to the question we study. The increase in net tax revenue from zoning additional land for retailing when the sales tax rate $\sigma$ rises is:

$$
\frac{\partial^{2} N T R}{\partial Z_{r} \partial \sigma}=S\left[1+\varepsilon_{S, Z_{r}}\right] \cdot\left[1+\varepsilon_{S, \sigma}\right]+\pi \frac{\partial V_{r}}{\partial \sigma}\left[\varepsilon_{V_{r}, Z_{r}}+1\right] .
$$

For simplicity, we have assumed that the elasticity terms in (2) are constants, and that $V_{m}$ and $\partial Z_{r} / \partial Z_{m}$ do not change with $\sigma$. The first term in (4) is the effect of the rise in the sales tax rate on sales tax revenues. It must be positive as long as $\varepsilon_{S, Z_{r}}>-1$ and $\varepsilon_{S, \sigma}>-1$. These inequalities require that sales per acre not decline so precipitously with increased zoning for retail use that total retail sales in jurisdiction $j$ would fall, and that sales per acre not decline so precipitously with a higher sales tax rate that total retail sales in jurisdiction $j$ would fall. The fact that jurisdictions zone any land for retail use and that they impose local sales taxes suggest that these two elasticity conditions are reasonable.

The second term in equation (4) is the effect of the rise in the sales tax rate on property taxes collected on land zoned for retailing. $\partial V_{r} / \partial \sigma$ is clearly negative, since the value of retail land is the discounted present value of future profits. The elasticity term that multiplies it captures the additional effect on property tax revenues that comes about because additional land zoned for retail use reduces the 
value of retail land per acre. The second term in (4) is negative as long as $\varepsilon_{V_{r}, Z_{r}}>-1$, which means that the value of retail land does not decline so precipitously as more land is zoned for retailing that total property tax revenue from retail land use in jurisdiction $j$ falls. ${ }^{9}$ But the second term is multiplied by the property tax rate—which in Florida is around $2 \%$ - so that it is small. ${ }^{10}$ Thus, equation (4) implies that the return to zoning more land for retail use increases with the sales tax rate, except in the anomalous case where zoning more land for retail use generates losses in property tax revenue that more than offset the gain from additional sales tax revenue.

Equation (4) being positive does not directly imply that the amount of land zoned for retailing increases in response to a higher sales tax rate, but rather just that the effect of this zoning on NTR increases with $\sigma$. To get a more specific prediction of how retail zoning is related to the sales tax rate, total differentiation of equation (2) with respect to $\sigma$ and $Z_{r}$ yields:

$$
d Z_{r} / d \sigma=\left\{\frac{S \cdot\left[\varepsilon_{S, \sigma}+1\right]\left[\varepsilon_{S, Z_{r}}+1\right]+\pi \frac{d V_{r}}{d \sigma}\left[\varepsilon_{V_{r}, Z_{r}}+1\right]}{\sigma \frac{d S}{d Z_{r}}\left[\varepsilon_{S, Z_{r}}+1\right]+\pi \frac{d V_{r}}{d Z_{r}}\left[\varepsilon_{V_{r}, Z_{r}}+1\right]+\pi \frac{d V_{m}}{d Z_{m}}\left(\frac{d Z_{m}}{d Z_{r}}\right)^{2}\left[\varepsilon_{V_{m}, Z_{m}}+1\right]}\right\} .
$$

The numerator is the same as equation (4). The denominator represents the additional effect of changing $Z_{r}$ when taking the total differential. We just argued that the numerator is positive. Under the same types of assumptions as earlier that all of the elasticity terms are greater than -1 , each term in the denominator must be negative, as $S$ and $V_{r}$ likely decline with increases in $Z_{r}$, and similarly $V_{m}$ declines with $Z_{m}$. Thus, coupled with the negative sign outside the brackets, the entire expression is positive.

Overall, then, it is profitable for jurisdiction $j$ to zone additional land for retailing when the local sales tax rate is higher as long as retail sales per acre do not fall too quickly as zoning for retail use increases, and sales and land values do not fall too quickly as the local sales tax rate increases. Although

\footnotetext{
${ }^{9}$ Note that the second term in equation (4) becomes positive if $\varepsilon_{V_{r}, Z_{r}}<-1$. If we think of the second term in (4) as the partial with respect to $Z_{r}$ of $\partial N T R / \partial \sigma$, then this means that the value of retail land falls sharply as $Z_{r}$ increases, implying that the property tax penalty from raising the sales tax rate becomes smaller.

${ }^{10} \partial V_{r} / \partial \sigma$ is likely to be a multiple such as 10 to 20 times $\partial S / \partial \sigma$, because the value of retail land equals the net present value of future sales. But $\partial V_{r} / \partial \sigma$ is multiplied by the small property tax rate.
} 
our model has not introduced a distinction between small retail stores and big-box or anchor stores, this point may provide a reason for local jurisdictions to respond to a higher sales tax by zoning more land for big box or anchor store development. Such development may generate more sales per acre, and have positive externalities on other retail establishments, hence at least partially offsetting the decline in $S$ from increases in $Z_{r}$. That is, $\varepsilon_{S, Z_{r}}$ is likely to be less negative for big box or anchor stores.

We can also solve for the effect on net tax revenues from zoning additional land for manufacturing when the local sales tax rate rises. The result (not shown) is the same as condition (4) multiplied by $\partial Z_{r} / \partial Z_{m}$. Assuming that $\partial Z_{r} / \partial Z_{m}$ is negative, this effect must be negative as long as (4) is positive. Thus, when the local sales tax rate rises, jurisdiction $j$ has an incentive to zone more land for retail use and less land for manufacturing use. Or, more precisely, if the jurisdiction has an incentive to zone more land for retail use, then it also has an incentive to zone less land for manufacturing use. Moreover, since it seems likely that there is a stronger tradeoff between land used for large retail developments and manufacturing than between land used for small retail stores and manufacturing, higher sales tax rates are likely to have a larger negative effect on the amount of land zoned for manufacturing because they make it more profitable for local officials to zone for big box stores and shopping centers.

Now consider how the local sales tax rate affects employment in retailing in jurisdiction $j$. To analyze this question, we must consider the incentives of retail firms. To keep the analysis simple, we treat all retail stores in a jurisdiction as though they were a single store occupying all of the land zoned for retailing. Retail profits are then:

$$
(1-\sigma) Q^{r}\left(Z_{r}, L_{r}, \sigma\right)-w L_{r}-(r+\pi) Z_{r} V_{r}\left(Z_{r}, \sigma, \pi, \tau\right)
$$

Here $Q^{r}$ denotes revenue from retail sales, which depends positively on inputs of land zoned for retailing $Z_{r}$, and labor $L_{r} . Q^{r}$ is also assumed to depend on the sales tax rate, since retailers may pass on sales tax increases by raising prices. We make the usual convexity assumptions for the retail production function, i.e., $Q_{L L}^{r}<0$ and $Q_{L Z}^{r}>0$, and we assume that the marginal revenue product of labor falls when the sales tax rate is higher, i.e., $Q_{L \sigma}^{r}<0$. The second term in (6) is the cost of labor, where the wage rate 
is denoted $w$, and third term in (6) is the rental cost of land per acre per year, $(r+\pi) V_{r}$, where $r$ is the interest rate. Retail firms hire labor until the marginal revenue product of labor equals the wage rate, or

$$
(1-\sigma) Q_{L}^{r}=w
$$

To consider how employment changes when jurisdiction $j$ 's sales tax rate is higher, we totally differentiate (7) and solve for $d L_{r} / d \sigma$. ( $w$ is assumed to be fixed on the assumption that it is set in a larger market.) The result is:

$$
\frac{d L_{r}}{d \sigma}=\frac{Q_{L}^{r}}{(1-\sigma) Q_{L L}^{r}}-\frac{Q_{L \sigma}^{r}}{Q_{L L}^{r}}-\frac{Q_{L Z}^{r}\left(d Z_{r} / d \sigma\right)}{Q_{L L}^{r}}
$$

This equation has three terms. The first captures the negative effect on retail employment from loss of revenue due to the higher sales tax rate, which must be negative. The second term captures the effect of the higher sales tax rate on the marginal revenue product of labor, which is also negative since $Q_{L \sigma}^{r}<0$, but is likely to be small. The third term captures the indirect effect of the sales tax change through zoning. Because the sales tax rate is higher, local officials zone more land for retailing, which raises the marginal revenue product of labor because the land-to-labor ratio in retailing rises $\left(Q_{L Z}^{r}>0\right)$. Thus, in the absence of zoning retail employment is predicted to be negatively related to the local sales tax rate. But with zoning, the relationship could become positive because local officials respond to higher sales taxes by zoning more land for retail use $\left(d Z_{r} / d \sigma>0\right)$. We test for this in our empirical work. Also, if the fiscal zoning response to an increase in the local sales tax rate is stronger for big box and anchor stores, then $d Z_{r} / d \sigma$ in equation (8) will be more positive, and we will be more likely to find a positive employment response to higher sales tax rates when we examine employment in large retail stores.

We can similarly model manufacturing employment using a single manufacturing firm that occupies all of the land zoned for manufacturing in jurisdiction $j$. Manufacturing profits are then:

$$
Q^{m}\left(Z_{m}, L_{m}\right)-w L_{m}-(r+\pi) Z_{m} V_{m}\left(Z_{m}, \pi\right)
$$

In equation (9), $Q_{m}$ denotes manufacturing revenue, which depends on inputs of land $Z_{m}$ and labor $L_{m}$. Manufacturing firms hire labor until the marginal revenue product of labor equals the wage rate, or 
$Q_{L}^{m}=w$.

Totally differentiating (10) and solving for $d L_{m} / d \sigma$, we get:

$\frac{d L_{m}}{d \sigma}=\frac{-Q_{L Z}^{m} \frac{d Z_{m}}{d Z_{r}} \frac{d Z_{r}}{d \sigma}}{Q_{L L}^{m}}$

This condition is similar to (8), but the first two terms in (8) drop out. Thus the local sales tax rate affects manufacturing employment only through its effect on the amount of land zoned for manufacturing. If there is no substitutability between the amount of land zoned for manufacturing versus retailing $\left(\partial Z_{m} / \partial Z_{r}=0\right)$, then (11) equals zero and the amount of employment in manufacturing is predicted to be unrelated to the sales tax rate. But if there is some substitutability $\left(\partial Z_{m} / \partial Z_{r}<0\right)$, then manufacturing employment is predicted to fall when the sales tax rises. Here, local officials zone less land for manufacturing when the sales tax rate is higher, which raises the cost of manufacturing land and reduces the marginal product of labor because the labor-to-land ratio in manufacturing rises. Equation (11) must be negative as long as $Q_{L L}^{m}<0$ and $Q_{L Z}^{m}>0$. We also test this prediction in our empirical work.

\section{Institutional Environment for Local Sales Taxes in Florida}

We use Florida data from 1992-2006 for our study. Florida has a state sales tax, which during our sample period was always $6 \%$. Counties in Florida can also adopt local sales taxes that are added to the state sales tax. Although property taxes are a more important source of revenue for Florida local governments than are local sales taxes, the latter are growing much more rapidly. After correcting for inflation, local sales tax revenue in Florida increased nearly three times as fast as property tax revenue between 1992 and 2008, rising from 1.9\% of local government tax revenue to 3.8\% (U.S. Census Bureau Census of Governments, 1992 and 2007). Thus, Florida is a good test case for studying the effects of increased reliance on local sales taxes.

Florida has seven separate local sales taxes. All are levied at the county level and apply uniformly all over the county; the overall local sales tax rate in a county is capped at $1.5 \%$. Tax revenues from two of these taxes - the infrastructure tax and the small county surtax — go directly to local governments 
(which in Florida are called municipalities). ${ }^{11}$ These two taxes are the most commonly-used local sales taxes in Florida and they account for most of the revenues. During our sample period, an average of 44 out of 67 Florida counties imposed one or both of these taxes and the average sales tax rate for the two taxes in counties using them was $0.96 \%$. Revenues from these two taxes are shared among municipalities either based on their shares of county population or on where the sales occurred. For revenues to be distributed according to where sales occurred, the county must adopt an interlocal agreement. ${ }^{12}$ During our sample period, around 35\% of counties that used these two taxes had interlocal agreements (Florida Legislative Committee on Intergovernmental Relations, 2003).

The other five local sales taxes are levied by counties but go to county-level special-purpose authorities, such as school boards, and health, welfare or transportation authorities. During our sample period, an average of only eight school boards, two health or welfare authorities, and one transportation authority levied local sales taxes. The average local sales tax rate for these taxes in counties that levied them was $0.48 \%$ during our sample period. See Table $1 \mathrm{~A}$ for information on local sales tax rates by type of $\operatorname{tax}^{13}$

Formally, land-use policy in Florida is set at the municipal level, while local sales tax policy is set at the county level. One issue is that municipal officials in Florida appear to have little incentive to engage in fiscal zoning, because the sales tax revenue that additional retailing would generate either goes to county-level authorities or is shared among municipalities within a county according to relative population. However counties that adopt local sales taxes clearly have an interest in attracting retailing and county officials have various ways of encouraging municipal officials to adopt zoning policies that

\footnotetext{
${ }^{11}$ The small county surtax can be used only by counties with populations less than 50,000 .

${ }^{12}$ Although county-specific interlocal agreements can be proposed by either the county or municipal governments, the governing bodies representing the majority of the respective county's municipal population must ultimately approve the agreements.

${ }^{13}$ School boards in Florida differ from other county-level authorities because they have independent authority to levy local sales taxes; other authorities' local sales taxes must be levied by the county. In all cases, adoption of a local sales tax is subject to a referendum and must be approved by voters. The school board tax is the School Capital Outlay Tax, the transportation tax is the Charter County Transit System Tax, and the health/welfare authority taxes are the Indigent Care and Trauma Center Tax (Dade County only), the County Public Hospital Tax (Dade County only), and the Indigent Care Tax. In addition, there are several other local sales taxes that we exclude from our study, including a tourist development tax, a convention center tax, and a professional sports facility tax. These are excluded because they are imposed on hotels/motels and therefore do not create incentives for local governments to expand retail activity. See Florida Legislative Committee on Intergovernmental Relations (2009 and earlier years).
} 
favor retailing. One method is for the county to adopt an interlocal agreement that distributes revenues from the local sales tax to municipalities based on where retail sales occur. Another method is for the county to directly reward municipalities that pursue fiscal zoning by giving them additional infrastructure. A third method is for county officials to engage in fiscal zoning directly by encouraging retail development in unincorporated areas; in these areas counties rather than municipalities are responsible for zoning. ${ }^{14}$

In our empirical work, we ignore the county-municipality distinction and treat counties as though they both decide the local sales tax rate and determine zoning policy. We therefore examine the fiscal zoning hypothesis using county-level data as our unit of analysis. This potentially raises endogeneity concerns, since sales tax rates could be set in response to changes in retailing or manufacturing activity. We examine this issue further in Section VI below.

Finally, an important advantage of using Florida data is that counties adopted local sales taxes or changed their rates fairly frequently during our study period. As of 1992, nearly half of Florida counties had no local sales taxes; by 2006, this figure had dropped to 13\%. Also, between 1992 and 2006, there were 75 changes in aggregate local sales tax rates and 32 instances of counties imposing a local sales tax where there was none before. Tables $1 \mathrm{~B}$ and 2 give a history of local sales tax rate changes by county over this period. Given that our empirical approach is based on a difference-in-differences analysis relating changes in employment to changes in county tax rates, this extensive within-county variation in sales taxes is essential to identifying the effects of sales taxes.

\section{Data and Approach}

We use panel data from the National Establishment Time Series (NETS) on the universe of individual business establishments in Florida from 1992 to 2006. For each establishment, we know employment each year and the establishment's name and industry. ${ }^{15}$ We aggregate these data to get total employment in retailing by county for each of the 67 Florida counties for each year from 1992 to 2006.

\footnotetext{
${ }^{14}$ Municipalities may nonetheless benefit by subsequently annexing the newly-developed land along with nearby areas (e.g., King, 2010; Shoer Roth, 2010).

${ }^{15}$ A detailed discussion of the NETS data along with assessment of its quality is provided in Kolko and Neumark (2007) and Neumark et al. (2007).
} 
Our basic model estimates how changes in local sales tax rates affect retail employment. As discussed in Section III, the predicted sign of this relationship is ambiguous; fiscal zoning tends to make it positive, but it will be less positive (or more negative) if the elasticity of retail sales is high relative to the amount of land zoned for retailing or relative to the sales tax rate. Another factor not discussed in the model is that competition across counties to attract retailing may be a zero-sum game, since one county's success may come at the expense of nearby counties if the area can only support a limited number of stores. To the extent that competition for stores results in success for some counties and failure for others nearby, then the estimated relationship will tend to be small. Given these offsetting factors, finding a positive relationship between changes in local sales tax rates and the level of retail activity would clearly provide evidence of fiscal zoning. ${ }^{16}$

One question is whether the level of retail employment is well suited to measuring the strength of fiscal zoning. A more direct measure would be the amount of land zoned for retail use. But land zoned for retailing is an imperfect measure of the level of retail activity, both because some of the land zoned for retailing may be vacant and because some stores may be vacant. Vacancies of both types may result if local government officials — particularly in high sales tax jurisdictions—zone too much land for retailing. In addition, as noted in Section I, local government officials can also encourage retailing by allowing land zoned for retailing to be developed at higher density levels or by expediting permit and inspection procedures. Using retail employment as our measure of the effect of fiscal zoning has the advantage that it encompasses all three policies and that it measures retail activity only for stores that are actually in operation.

Because large retail concentrations are particularly valuable in areas with higher local sales tax rates, we also examine the effect of fiscal zoning on retail employment in big box stores, such as WalMart, Home Depot, and Costco, and department stores of the type that anchor large shopping malls, such as Macy's. Our hypothesis is that local government officials in jurisdictions that have high local sales

\footnotetext{
${ }^{16}$ An additional factor is that the price elasticity of demand for goods bought from brick-and-mortar stores has been increasing over time as sales migrate to the internet. See Goolsbee and Zitran (1999).
} 
taxes are particularly likely to compete for these stores and the associated shopping malls. ${ }^{17}$

We also estimate similar models for manufacturing employment. Here the hypothesis is that county-level manufacturing employment will fall in response to higher local sales tax rates. As discussed in Section III, this is because local government officials have less incentive to zone for manufacturing than for retailing and also because manufacturing may be crowded out by retailing. And finally, manufacturing is of interest from a policy standpoint, since local governments' efforts to attract retailing may come at the expense of attracting better-paid jobs in manufacturing (Leroy, 2005). ${ }^{18}$

Table 3, Panel A, gives summary statistics for our county-level sample. All sales tax rates are the sum of the state plus local sales tax rates. The neighboring sales tax rates in the county-level sample are a weighted average of the sales tax rates in all bordering counties, using the lengths of the borders with each neighboring county as weights. ${ }^{19}$ Sales tax rates in Florida ranged from $6.0 \%$ to $7.5 \%$ during our sample period, while sales tax rates in the neighboring counties in Alabama and Georgia (which also use local sales taxes) ranged from $5.0 \%$ to $7.0 \%{ }^{20}$ The table also shows that employment levels vary widely. For example, in the county-level sample, the range is from near zero to 241,000 jobs in retailing and from near zero to 112,000 jobs in manufacturing.

Finally, as we describe in more detail in Section VII, we also examine a separate sample in which counties are divided into border versus interior regions.

\section{County-level Specifications and Results}

\section{Empirical Approach}

\footnotetext{
${ }^{17}$ The list of stores we study includes Best Buy, Big Lots, Bloomingdales Inc., Circuit City, Costco, Federated Retail Holdings (Lord \& Taylor), Home Depot, J.C. Penney, K-Mart, Lowes Home Centers, Macy's, May Department Stores, Montgomery Ward, Neiman Marcus Group Inc., Nordstrom Inc., Office Depot, Office Max, Saks \& Company, Sears Roebuck, Staples, Target Corporation, and Wal-Mart. The list of big box retailers is taken from Mazzolari and Neumark (forthcoming) and we added additional stores identified as those that anchor malls in Florida, from Oyston (2007).

${ }^{18}$ We would have liked to run our model on other sectors in addition to retailing and manufacturing, such as office employment and services. But in order to run our model on a particular sector, firms must be in a sector that is identified in the NETS data (where sectors in the NETS are identified by SIC codes) and the sector must also be a zoning classification so that local officials have a means of encouraging or discouraging it. Offices are a zoning classification, but office employment is not identified in the NETS data; in contrast, service employment is identified as a sector in the NETS data, but is not a zoning classification.

${ }^{19}$ To account for coastline and not overweight land borders, we include coastline as part of the border, using the county's own tax rate as the tax rate on this border.

${ }^{20}$ Data are from Georgia Department of Revenue (2011) and Alabama Department of Revenue (n.d.).
} 
Our base case model, for the analysis of the effects of sales tax rates on county-level retail employment, is the following:

$$
\begin{aligned}
\ln R E_{c t} & =\alpha+\beta_{1} \operatorname{tax}_{c t}+\beta_{2} \operatorname{tax}_{\mathrm{c}, t-1}+\gamma_{1} \text { neighbortax }_{c t}+\gamma_{2} \text { neighbortax }_{c, t-1} \\
& +D_{c} \delta+D_{t} \lambda+D_{c} t \theta+\varepsilon_{c t} .
\end{aligned}
$$

In equation (12), $R E_{c t}$ is retail employment in county $c$ in year $t$. The variables $\operatorname{tax}_{c t}$ and $\operatorname{tax}_{\mathrm{c}, t-1}$ are the sums of the state plus local sales tax rates in county $c$ in the current year and the previous year, respectively, while neighbortax $c$ and neighbortax ${ }_{c, t-1}$ are the weighted averages of the same sales tax rates in county c's neighboring counties (including counties across state borders) in the current year and the previous year, respectively. $D_{c}$ and $D_{t}$ are county and year fixed effects, and $D_{c} t$ is a set of county-specific linear time trends.

The coefficients of interest are $\beta_{1}$ and $\beta_{2}$ and their sum, or the percentage change in retail employment when the sales tax rate in the current year and/or the previous year rises by one percentage point, holding neighboring counties' sales tax rates fixed. Note that because the Florida general sales tax rate was $6 \%$ throughout our sample period, all changes in sales tax rates are due to changes in local sales tax rates. Therefore, what we identify is the effect of variation in local sales tax rates only, and identification comes from changes in individual counties' sales tax rates over time. The county fixed effects control for time-invariant differences between counties in unmeasured county-specific characteristics that may affect the level of retail employment, while the year fixed effects and countyspecific time trends capture any national changes and local trends in retail employment. The countyspecific trends, in particular, are intended to capture sources of endogenous variation stemming from trends in retail growth that could affect sales taxes, an issue we discuss more in the next section. We estimate equation (1) using OLS. Robust standard errors are clustered at the county level to allow for arbitrary patterns of serial correlation within counties and for heteroscedasticity across counties.

For the county-level analysis, we report both unweighted regressions and regressions weighted by 1992 county population levels, which are closely related to county employment levels at the beginning of 
our sample period. ${ }^{21}$ Because county population and employment levels vary widely in Florida, the weighted estimates of how sales tax rates affect retail employment are more representative of how the average individual is affected. Moreover, the unweighted data give us some high estimates of marginal effects, because increases in employment can be very high in percentage terms when they start from a low base. On the other hand, using weights in effect reduces the influence of these extreme measurements in small counties. ${ }^{22}$

\section{Basic Results}

Results of regressions explaining total retail employment are shown in Table 4A. The results in columns (1) and (1') include only the current sales tax rates, while those in columns (2) and (2') include both the current and lagged sales tax rates. They show that total retail employment is not significantly related to sales tax rates, regardless of whether weights are used and whether we include the lagged sales tax rate in addition to the current rate. This is true for the individual coefficient estimates, as well as for the sums of the current and lagged sales tax rates, which are shown in the second-to-last row of the table. The summed effect of the current plus lagged sales tax rate on total retail employment is positive- - which is consistent with fiscal zoning-but statistically insignificant. In columns (3) and (3') we add the neighboring counties' sales tax rates, both current and lagged, to isolate the effects of independent variation in local sales tax rates. The coefficients of the own local sales tax variables remain insignificant, and are largely unchanged. Thus our results suggest that fiscal zoning by counties with high local sales tax rates does not result in a significant increase in total retail employment. This may reflect the offsetting positive effect of fiscal zoning and negative effect of sales taxes on prices.

In Table 4B we report estimates of the same regression models, but our dependent variable is employment in big box and anchor stores only. Here the coefficient of the current sales tax rate is positive and significant at the 5\% level in the weighted regression shown in column (1'), and at the $10 \%$ level in

\footnotetext{
${ }^{21}$ County population estimates for 1992 were supplied by the Bureau of Economic and Business Research, University of Florida.

${ }^{22}$ When we use a dataset that constructs aggregates from a sample, we normally must worry about heteroscedasticity driven by variation in the number of observations from which the aggregates are estimates. However, in the case of the NETS we have the universe of business establishments, not a sample.
} 
column (1). Also the combined coefficient of the current and lagged sales tax rates is positive and significant in the weighted regressions in columns (2') and (3'), regardless of whether the neighboring sales tax rate is included or not. For the latter specification, the sum of the unweighted estimates is positive and statistically significant as well (column (3)). The weighted regression results suggest that employment in big box and anchor stores rises by $15 \%$ to $17 \%$ for each percentage point increase in the local sales tax rate. In elasticity terms, the increase is around 0.9 to 1.1 . The unweighted regression results are larger, but they may be influenced by large employment changes from a small base in sparselypopulated counties (which are down-weighted in the weighted estimates). Overall, these results indicate that local officials focus their fiscal zoning efforts on big box stores and shopping centers when sales tax rates rise, and their efforts are successful.

Another implication of the strong positive relationship between higher sales tax rates and employment in big box and anchor stores is that large retail establishments and shopping malls may crowd out smaller retail establishments in counties that impose a local sales tax. If this were true in general, it might be a contributing factor to our finding of an insignificant relationship between the local sales tax rate and total retail employment. To test this hypothesis, we estimated the effect of the local sales tax rate on small store retail employment, which we define as total retail employment minus employment in big box and anchor stores. The results, which are reported in Table 4C, show that small store retail employment is not significantly related to local sales tax rates, although the point estimates are negative. These results suggest that big box/anchor stores do little to crowd out smaller stores, and that local government officials do not try to attract small stores in response to higher sales taxes.

Finally, Table 4D reports the results of regressions explaining manufacturing employment. The estimated effects - including the contemporaneous effects in columns (1) and (1') and the summed effects in columns (2)-(3') - are always negative, but never significant. However, in these latter specifications, the lagged effect of the sales tax rate is always significant at the $5 \%$ or $10 \%$ level. We therefore reestimated the models with only a lagged effect. As shown in the columns (4) and (4') of the table, the estimated effect of the lagged sales tax rate is negative and significant at the $10 \%$ level in the unweighted 
estimate, and negative and significant at the 5\% level in the weighted estimate. These point estimates suggest that when the sales tax rate rises by one percentage point, employment in manufacturing falls by $7 \%$ to $9 \%$. The implied elasticities are -0.5 to $-0.6{ }^{23}$

Since the results are sometimes sensitive to weighting (particularly our results for big box and anchor store employment), they may be influenced by large employment changes from a small base in sparsely-populated counties. We verified this by re-estimating the models for big box/anchor store and manufacturing employment with additional terms that interacted the sales tax rate and (linear and quadratic terms in) the same measure of population that we used as weights. When we did this, the estimated interactions confirmed that the key results in Tables 4B and 4D are in fact stronger in areas with smaller baseline populations. Moreover, the results were less sensitive to whether or not we used weights, and the qualitative conclusions were the same based on the weighted and the unweighted estimates. ${ }^{24}$

\section{Threats to Identification}

The key identifying assumption for the specifications in Tables 4A-4D is that local sales tax rates are uncorrelated with the residuals in our equation (12) explaining retailing and manufacturing employment. One potential source of correlation is other policies that could have changed over time at different rates in different counties, yet influenced (or been associated with) both sales tax rates and retail or manufacturing employment. The policy most likely to fit this description is the Florida Enterprise Zone program, which offers tax credits against sales and use taxes to firms that locate within a zone and create new jobs. An earlier program was terminated in 1994, and a new program was launched in 1995, beginning with zones in 18 counties, and spreading to 43 counties by the end of our sample period. ${ }^{25}$ It is possible that enterprise zones were established in areas that were losing manufacturing jobs and that they generated new retailing jobs. Given the tax credit, enterprise zones would have been more valuable to

\footnotetext{
${ }^{23}$ Note that the evidence of negative effects of sales tax rates on manufacturing employment does not imply that manufacturing plants are closed as a result of sales tax increases. First, the estimates are relative, so a negative effect can simply mean that manufacturing employment grows more slowly in counties that raise sales tax rates. Second, establishments frequently die, and are replaced by other establishments. Changes in use of particular sites may reflect changes in land use after manufacturing facilities close.

${ }^{24}$ These results are not reported in the tables, but are available from the authors upon request.

${ }^{25}$ Data on enterprise zones by county comes from the Florida Department of Economic Opportunity (personal communication with Burt C. Von Hoff, January 22, 2012) and Executive Office of the Governor (2007). To the best of our knowledge, there are no other subsidies targeted to retailers in Florida.
} 
employers in areas with high sales tax rates, hence potentially generating our results via a mechanism different than our fiscal zoning hypothesis. ${ }^{26}$

To test whether the effects of sales taxes are confounded with the effects of enterprise zones, we coded a dummy variable equal to one in county-years in which an enterprise zone exists and we added that variable to our models explaining employment in big box/anchor stores and in manufacturing. The results are reported in Table 5. The time period covered is $1996-2006,{ }^{27}$ and because of the shorter sample period, for each specification we first report the baseline estimates for this shorter sample period without including the enterprise zone control (the columns without primes), which change a bit from Tables 4B and $4 \mathrm{C}$. The key question is the sensitivity of the estimates to including the enterprise zone control. The table makes clear that there is no evidence that enterprise zones account for the effects of sales taxes on big box/anchor store employment or manufacturing employment. For both types of employment, the estimated effects of sales taxes with and without the enterprise zone control are virtually identical.

A second threat to identification is the possibility that local sales tax rates could respond to changes in retailing or manufacturing employment. For example, an exogenous increase in retail sales might cause counties to raise their local sales tax rates in order to capture more revenue. In this case, endogeneity would generate a positive bias in the estimated relationship between sales tax rates and retail (or big box/anchor store) employment. However, the bias could alternately go in the opposite direction, because an exogenous decrease in retail sales might cause counties to raise their local sales tax rates in order to maintain tax revenues at the past level. These possibilities could bias our results by generating spurious evidence that could be either consistent with or contrary to the fiscal zoning hypothesis.

As noted earlier, we included county-specific time trends in the specifications in Tables 4A-4D to capture the possibility that sales tax rates might have changed endogenously in response to underlying

\footnotetext{
${ }^{26}$ On the other hand, there could be a bias in the opposite direction. Because the Florida EZ program allows the hiring credit to be taken against the sales tax collections that a business owes, an enterprise zone could reduce the attractiveness of a retail business to a county (at least from the perspective of sales tax revenue). In this scenario, if enterprise zones are created where sales tax rates are high, the estimated effects of sales taxes on retail employment could be biased toward zero, which would only strengthen our finding.

${ }^{27}$ Although the new enterprise zones went into effect in 1995, we start our analysis in 1996 because we include oneyear lags of sales tax rates.
} 
changes in employment. When we re-estimate the models without county-specific time trends, the effect of sales tax rates on total retail employment remains small, slightly positive, and insignificant; these results suggest that for overall retail employment there is not an endogeneity problem. ${ }^{28}$ When the models for big box/anchor retail employment are re-estimated without county-specific trends, the effect of sales tax rates remains positive, but becomes smaller and insignificant. This is the opposite of what we would expect if trend growth in employment led to the adoption of higher sales tax rates, and instead is consistent with a slight tendency for tax rates to increase when trend growth is negative. The findings for big box/anchor retail employment imply that it is important to include the county-specific time trends as a partial control for endogeneity. More substantively, they suggest that the positive effects of sales tax rates on big box/anchor retail employment that we find are not driven by endogeneity.

We also did a more direct analysis of whether local sales tax rates are endogenous, by testing whether lagged changes in employment are related to changes in county-level sales tax rates. In these regressions, the dependent variable is the change in the local sales tax rate and the independent variables are the first, second, and third lags of the change in total retail employment, big box/anchor employment, or manufacturing employment; other control variables are the same as in Table $4 .{ }^{29} \mathrm{We}$ found no evidence that lagged changes in any of the employment measures predict changes in local sales tax rates: the estimated coefficients of the lagged employment variables were small and always individually and jointly insignificant. These results provide additional evidence that local sales tax rates are not endogenously determined by changes in employment; in other words, counties do not change their sales tax rates in response to increases in total retail sales or big box/anchor store sales. Overall, these additional analyses indicate that the county-level results are driven by exogenous changes in sales taxes.

Another potential identification issue is whether the key assumption underlying the difference-indifferences approach holds. Namely, this approach assumes that the policy change affects the area where the policy is implemented, but does not affect the "control" areas. If this assumption is violated and there

\footnotetext{
${ }^{28}$ Results discussed in this section but not reported in the tables are available from the authors upon request.

${ }^{29}$ Since the baseline models have county fixed effects and county-specific linear time trends, in the first-differenced model the original county fixed effects drop out, and the county-specific time trends become county dummy variables.
} 
are important cross-border effects, then the estimated sales tax coefficient could be biased; for example, if an increase in one county's local sales tax rate reduces sales in that county but increases sales in neighboring counties, then the effect of the sales tax would be overstated. However, the estimates in the preceding tables always suggest that the effects of neighboring counties' tax rates are near zero and statistically insignificant. We return to this question in Section VII when we discuss the effects of sales taxes in border versus interior regions of counties.

\section{Dynamics}

The results for big box and anchor store employment and for manufacturing employment, in Tables 4B and 4D, sometimes point to evidence that the effects of sales taxes arise with a one-year lag. We would not expect the effects of sales tax changes to be instantaneous, so the evidence of some lag in the effect is plausible; on the other hand, we might also expect some anticipation effects, as behavior begins to respond to future sales tax changes that are already enacted.

The standard within-group estimator may not pin down the dynamics of the effects of sales taxes very well, because the estimator uses deviations from means over all years for each county. For example, even if all of the effect occurs, say, two years after the sales tax changes, if the two-year lag is omitted one will still find an apparent "effect" of the contemporaneous sales tax rate, because its coefficient is identified from the partial correlation between the deviation of big box employment (for example) from its sample average for the county, and the deviation of the sales tax rate from its sample average for the county. To better pin down the dynamics, we also estimated first-difference models with additional lags. We estimate these models using one-year first differences, which are standard, but also using two-year first differences, which may be less noisy. ${ }^{30}$ The results are reported in Panel A of Table 6 for big box/anchor retail employment and for manufacturing employment. The results are robust, and point to effects that are not instantaneous, but that emerge over two to three years. For manufacturing, the cumulative effects of the lagged sales tax variables are larger than the estimates in Table $4 \mathrm{D}$, although the

\footnotetext{
${ }^{30}$ Taking first differences induces serial correlation in the errors. (This is also a problem, although less severe, in standard within-group estimation.) However, clustered standard errors take account of this non-independence among observations for a county.
} 
sample is a bit smaller because we have to drop observations.

Panel B reports specifications where we add one- or two-year leads to the model. We report the lead effect, the sum of the contemporaneous and lagged effects, and the sum of all the effects including the lead. We also report, for comparison, the sum of the contemporaneous and lagged effects using the same sample but omitting the lead. There is sometimes evidence of a lead effect, which is not unanticipated. But the contemporaneous and lagged effects are robust to the inclusion of this lead. Thus, the combined results indicate that there is some anticipation effect of sales taxes, but most of the effect unfolds over two to three years.

A different perspective on dynamics concerns how the changes in big box and anchor store employment come about. If the effects on sales taxes arise through fiscal zoning and other efforts by local government officials to attract retail stores, then we should find that higher local sales taxes are associated with more creation or relocation of new businesses. The NETS data are nicely suited to this question, since we can identify when an establishment first has positive employment in a county; see Neumark et al. (2007) for details. To verify that employment growth is generated by new establishments rather than growth of existing establishments, we measure the employment change created by new establishments in a county, and we estimate similar models as those in Table 4B. Here the dependent variables are in levels rather than logs, since there are many zeros. The results are reported in Table 7, for new establishments defined over both one-year and two-year windows. The estimates always indicate positive effects of sales tax increases, which are statistically significant in three out of the four cases shown in the table. Moreover, the magnitude of the estimates suggests that a one-percentage point increase in the sales tax rate leads to the opening of one or two big box or anchor stores (122-164 employees). ${ }^{31}$

\section{Border-Interior Specifications and Results}

Local government officials' incentives to encourage retailing may differ in interior versus border regions of counties, and evidence of such differences can help confirm and refine the fiscal zoning hypothesis. Since sales tax rates may differ on either side of county borders, consumers have an incentive

\footnotetext{
${ }^{31}$ Descriptive statistics indicate that new big box or anchor stores have about 87-90 employees.
} 
to shift their shopping to the lower-tax side. This means that the price elasticity of demand will tend to be higher near county borders than in county interiors, which undermines the effectiveness of fiscal zoning in border areas. We therefore predict that the relationship between local sales tax rates and retail employment will be less positive/more negative near county borders than in county interiors, taking account of cross-border sales tax differentials.

To construct border versus interior regions, we use ArcGIS software to determine whether each establishment in the NETS is within 1 mile of a county border, and we assign each establishment to the county's interior versus its border. We further subdivide each county's border into separate regions for each neighboring county and we identify the neighboring county for each region. Parts of the border that are within one mile of more than one neighboring county are deleted, so that each border region has a unique cross-border county (which may be in a different state).$^{32}$ Border regions along the coast are combined with county interiors. Finally, we aggregate each type of employment within each border and interior region. This procedure increases the sample size from 67 counties to 277 border or interior regions. For each border region, the neighboring sales tax rate is now the actual sales tax rate across the border, while for interior regions, the neighboring sales tax rate is set equal to the own sales tax rate. Table 3, Panel B, gives summary statistics for the border-interior sample.

In the border-interior regression models, employment by sub-county region-year replaces employment by county region-year as the dependent variable, fixed effects for sub-county regions replace the county fixed effects in equation (12), and we still include interactions between a time trend and county dummies. We also create a dummy variable that equals one for border regions and we add interactions between the border dummy and the sales tax rate. These interaction terms allow us to estimate (and test for) differences between border versus interior regions in the effects of sales tax rates on employment. We report only unweighted estimates for the border-interior regressions. Because the sub-county regions tend

\footnotetext{
${ }^{32}$ To illustrate our procedure, suppose a county is shaped like a square with sides of 10 miles in length, and has one neighboring county on each side. Our procedure divides the county into nine sub-county regions: one square interior region having sides of length 8 miles, four rectangular border regions that are each one mile by 8 miles, and four square corner regions that are each one mile square. The corner regions are dropped because they border more than one neighboring county.
} 
to be small, many individuals live and work in different regions. Thus population-based weights are less accurate in representing employment levels and weighted regressions are therefore less informative. Standard errors are clustered at the sub-county region level.

The results of the border-interior regressions explaining total retail employment are shown in Table 8A. Columns (1)-(3) repeat the earlier specifications at the sub-county region level, without interactions between the sales tax rate and border dummies. As in Table 4A, none of the sales tax rate coefficients or their sums are significant. In columns (4)-(6) we add the border dummy-sales tax rate interactions. The estimated interaction coefficients capture the difference between the effects of sales tax rates on retail employment in border versus interior regions. The estimated interaction terms are small and insignificant, whether looking at individual coefficient estimates or summed current and lagged effects. Thus they indicate no detectable difference between border versus interior regions in the effect of sales tax rates on overall retail employment.

However when we turn to employment in big box/anchor stores, in Table 8B, we find pronounced differences between border versus interior regions. Columns (4)-(6) show the key results. In column (4), the effect of the current sales tax rate on big box/anchor store employment in interior regions is positive and significant at the $5 \%$ level (the 0.405 estimate); while in columns (5) and (6), the combined effect of the current and lagged sales tax rate is positive and significant at the $10 \%$ or $5 \%$ level (the estimates of 0.404 and 0.483 ). In contrast, the results for border regions show that an increase in the current and lagged sales tax rate causes big box/anchor employment to fall; the estimated effect in columns (4)-(6) is around -0.15 and significant at the $5 \%$ level (the estimates of $-0.150,-0.167$ and -0.148 ).

Thus our results show that a one percentage-point increase in the sales tax rate leads big box/anchor store employment to rise by $40-48 \%$ in interior regions and to fall by $15-17 \%$ in border regions. The implied elasticities are around 3.0 and -1.1 , respectively. The fact that our estimates in interior regions are positive is contrary to the general literature on the effects of sales taxes, which almost uniformly finds negative values. ${ }^{33}$ While our point estimates are perhaps implausibly large, we also found

\footnotetext{
${ }^{33}$ See Wasylenko (1997) for a survey.
} 
rather large point estimates when we did not use weights in the county-level analysis of big box/anchor employment (Table 4B). Thus, although our point estimates are high, we are more confident in our qualitative conclusions.

These estimates suggest that local officials concentrate their fiscal zoning efforts on attracting big box stores and shopping centers and that their efforts are successful in interior regions, where there is no competition from across the border. But in border regions, fiscal zoning is either counter-productive or it cannot overcome the negative effect of tax-induced price increases in the presence of cross-border competition.

Table $8 \mathrm{C}$ reports results of the border-interior analysis for manufacturing. Interestingly, the results are the opposite of those we found for retail employment at big box/anchor stores. Looking again at columns (4)-(6), the estimated interaction between the sales tax rate and the border dummy is positive and, for the current tax rate, significant. Computing the implied effects in border and interior regions, we find that an increase in the sales tax rate has a negative effect on manufacturing employment in interior regions (significant only in column (6)) and a positive effect in border regions. The estimated effects in border regions are never significant, but the differences between border and interior regions are strongly significant. Although this evidence is statistically weaker than the evidence for big box/anchor store employment, it is consistent with the existence of tradeoffs between employment in big box and anchor stores and employment in manufacturing. Thus fiscal zoning leads to both increased big box/anchor store employment and reduced manufacturing employment in interior regions. These results presumably reflect the fact that land in interior regions is more valuable for generating sales tax revenue, since there is less competition from stores across the border. ${ }^{34}$

The 1-mile width that we used to define border areas is somewhat arbitrary; our idea was to isolate areas very close to county borders where nearby residents would not regard cross-county travel as costly. In order to explore the sensitivity of our results to how we defined the borders, we re-estimated the

\footnotetext{
${ }^{34}$ Endogeneity is less of a concern for the border-interior analysis, because these smaller regions clearly have less influence over sales tax rates. Consistent with this expectation, when we estimated the key specifications excluding the county time trends, the qualitative conclusions were unchanged, although the significance of some of the estimates changes.
} 
same specifications as in Tables $8 \mathrm{~A}-8 \mathrm{C}$, but redefined the border regions to be 2 miles wide. The resulting estimates were qualitatively similar, although statistically weaker.

Finally, we revisited the question of dynamics, using the one- and two-year first-difference specifications to estimate similar models for big box and anchor retail employment and for manufacturing employment, paralleling what we did in the county-level analysis in Table 6 . The estimates were qualitatively similar to those in Tables $8 \mathrm{~B}$ and $8 \mathrm{C}$. For manufacturing, there is statistically significant evidence of negative effects in the county interior, again developing over a few years, although in this case (and the sample period is shorter) the contrast between the border and interior regions is not as clear. For big box and anchor store employment in the county interior, there are positive effects in the county interior (significant in the two-year first difference) that evolves over three years, and negative effects in border regions that similarly evolve over time. ${ }^{35}$

\section{Conclusion}

We have three main findings. First, total retail employment is not significantly affected by local sales tax rates. Second, however, local sales tax rates have a strong positive effect on employment in big box stores and department stores that anchor shopping centers. And third, local sales tax rates have a negative effect on manufacturing employment, although this evidence is weaker statistically.

Our results suggest that local officials concentrate their fiscal zoning efforts on attracting large stores and shopping centers. This is presumably because these stores generate high sales tax revenues, both directly and indirectly by attracting small stores. These stores also require large sites, which means that they need the types of zoning changes or other assistance that local officials can provide. In contrast, stores in neighborhood shopping centers and stores that occupy downtown or "main street" locations are less likely to require zoning changes or other assistance from local officials.

We also find that the effects of fiscal zoning on employment in big box/anchor stores differ substantially in border versus interior regions of counties. Fiscal zoning has strong positive effects in interior regions, but not in border regions. This may be because shoppers in interior regions are captive,

\footnotetext{
${ }^{35}$ These results are available from the authors upon request.
} 
making it easier for local officials to attract retail development despite higher sales tax rates. But in border regions, tax competition appears to be more important, making local officials' efforts less productive.

In some ways manufacturing provides a cleaner test of the effects of fiscal zoning, assuming that it competes with retailing for land, because it does not have the contaminating direct price effect that pulls in the opposite direction; on the other hand, the effects of sales taxes on manufacturing may not be as strong, especially if the substitutability of zoning for retail versus manufacturing use is relatively weak. Our results suggest that sales taxes have the opposite effects on manufacturing employment as on big box/anchor store employment, so that local officials' efforts to attract shopping centers crowd out manufacturing.

Our evidence feeds into a larger debate about the effects of using different types of taxes to fund local government. Over the past several decades, many states have moved to limit local governments' reliance on property taxes - their traditional funding source — and to substitute other sources of revenue, including local sales taxes. Florida is among the states that have done so. ${ }^{36}$ But while property taxes give local governments an incentive to encourage all non-residential land uses, local sales taxes give them an incentive to favor retail stores in particular. Our results provide empirical evidence that when sales tax rates are higher, local governments use fiscal zoning to encourage retailing and discourage manufacturing. Using the elasticities from the weighted estimates discussed above, ${ }^{37}$ our basic results predict that a 1 percentage point increase in the local sales tax rate in a county leads to approximately 258 additional jobs in big box or anchor stores, but approximately 838 fewer manufacturing jobs. ${ }^{38}$ Thus, our results suggest that fiscal zoning causes both a large substitution of jobs in retailing for jobs in manufacturing and a substitution of lower-wage jobs for higher-wage jobs. Both the loss of jobs and the loss of higher-wage jobs are clearly harmful to local residents and the local economy.

\footnotetext{
${ }^{36}$ See Advisory Commission on Intergovernmental Relations (1995) for information on property tax limitation measures in all U.S. states. Florida adopted a property tax limitation measure in 1992 (implemented in 1995) that prevents property assessments from rising by more than the minimum of the inflation rate or 3\% per year.

${ }^{37}$ See the discussion of Tables 4B and 4D.

${ }^{38}$ There may be some additional job growth in subsectors of retail that gain from the growth of big box stores or malls, such as small stores in malls.
} 


\section{References}

Advisory Commission on Intergovernmental Relations. 1995. Tax and Expenditure Limits on Local Governments. M-194 (March).

Alabama Department of Revenue. n.d. Sales, Use, Lodging and Rental Tax Rates - Detail Report, https://www.revenue.alabama.gov/salestax/sales/index.cfm (viewed January 25, 2011).

Epple, Dennis, and Allan Zelenitz, 1981. Implications of Competition Across Jurisdictions: Does Tiebout Need Politics? Journal of Political Economy 89:6, 1197-1217.

Executive Office of the Governor. 2007. Florida Enterprise Zone Program Annual Report, October 1, 2005 - September 30, 2006, Office of Tourism, Trade \& Economic Development, http://www.hillsboroughcounty.org/econdev/resources/publications/enterprise/annualreport.pdf (viewed January 23, 2012).

Fischel, William A. 1992. Property Taxation and the Tiebout Model: Evidence for the Benefit View of Zoning and Voting, Journal of Economic Literature 31:1, 171-177.

Florida Department of Revenue. 2010. History of Local Sales Taxes and Current Rates, https://taxlaw.state.fl.us/wordfiles/SUT\%20TRC\%20HISTORY.pdf (viewed September 16, 2010).

Florida Legislative Committee on Intergovernmental Relations. 2009. 2009 Local Government Financial Information Handbook, www.floridalcir.gov/UserContent/docs/File/reports/lgfih09.pdf (viewed September 8, 2010).

Florida Legislative Committee on Intergovernmental Relations. 2003. 2003 Local Government Financial Information Handbook, http://www.floridalcir.gov/UserContent/docs/File/reports/lgfih03.pdf (viewed March 31, 2010).

Fulton, W. 1998. Twenty Years of Proposition 13; Tax-Cutting Initiative Shaped Planning and Development in State, California Planning and Development Report, 13:6, http://www.cpdr.com/node/1606 (viewed September 8, 2010).

Georgia Department of Revenue. 2011. Sales and Use Tax - Historical Chart, https://etax.dor.ga.gov/salestax/salestaxrates/LGS_2011_Jan_Rate_Chart_Historical.pdf (viewed January 25, 2011).

Goolsbee, Austan, and Jonathan Zitran. 1999. Evaluating the Costs and Benefits of Taxing Internet Commerce, National Tax Journal 52:3, 413-428.

Gordon, Roger, and Wei Li. 2012. Provincial and Local Governments in China: Fiscal Institutions and Government Behavior, in Capitalizing China, J. Fan and R. Morck, eds., NBER and the University of Chicago Press.

Hamilton, Bruce. 1975. Zoning and Property Taxation in a System of Local Governments, Urban Studies 12:2, 205-211 (June).

Hawkins, Richard, and Matthew N. Murray. 2004. Explaining Interjurisdictional Variations in Local Sales Tax Yield, Public Finance Review 32:1, 82-104.

King, Dale M. 2010. Three Areas Eyed for Annexation to Boca Would Net City \$2.5 Million, Says Consultant, The Boca Raton Tribune, June 16, http://www.bocaratontribune.com/three-areaseyed-for-annexation-to-boca-would-net-city-2-5-million-says-consultant/ (viewed March 30, 2011).

Kolko, Jed, and David Neumark. 2007. Business Location Decisions and Employment Dynamics in California, San Francisco, CA: Public Policy Institute of California.

LeRoy, Greg. 2005. The Great American Jobs Scam, San Francisco: Berrett-Koehler Publishers, Inc.

Lewis, Paul G., 2001. Retail Politics: Local Sales Taxes and the Fiscalization of Land Use, Economic Development Quarterly 15:1, 21-35.

Lewis, Paul G., and Elisa Barbour. 1999. California Cities and the Local Sales Tax, San Francisco, CA: Public Policy Institute of California.

Mark, Stephen T., Teresa McGuire, and Leslie Papke. 2000. The Influences of Taxes on Employment and Population Growth: Evidence from the Washington, D.C. Metropolitan Area, National Tax Journal 53:1, 105-24. 
Mazzolari, Francesca, and David Neumark. Forthcoming. Immigration and Product Diversity, Journal of Population Economics.

Misczynski, Dean J. 1986. The Fiscalization of Land Use, in California Policy Choices, J.J. Kirlin and D.R. Winkler, eds., Sacramento, CA: School of Public Administration, University of Southern California, 127-50.

Neumark, David, Junfu Zhang, and Brandon Wall. 2007. Employment Dynamics and Business Relocation: New Evidence from the National Establishment Time Series, Research in Labor Economics 26, 39-84.

Ohls, James C., Richard Chadbourn Weisberg, and Michelle J. White. 1974. The Effect of Zoning on Land Value, Journal of Urban Economics 1:4, 428-44.

Oyston, Joyce. 2007. Largest Shopping Malls in the U.S., http://www.sutie101.com/content/largestshopping-malls-in-the-us-a27524 (viewed September 16, 2010).

Schrag, Peter. 1998. Paradise Lost: California's Experience, America’s Future, Berkeley, CA: University of California Press.

Shoer Roth, Daniel. 2010. Annexation Opponents Destined to Repeat Pleas, Miami Herald, April 6, http://www.miamiherald.com/2010/04/06/1564987/annexation-opponents-destined.html (viewed March 30, 2011).

Sonstelie, John C., and Paul R. Portney. 1978. Profit Maximizing Communities and the Theory of Local Public Expenditure, Journal of Urban Economics 5:2, 263-277.

Tiebout, Charles M. 1956. A Pure Theory of Local Expenditure. Journal of Political Economy 64:5, 416424.

U.S. Census Bureau. 2007. Census of Governments, http://www.census.gov/govs/estimate/historical_data_2007.html\#state_local (viewed January 23, 2012).

U.S. Census Bureau. 1992. Census of Governments, http://www.census.gov/govs/estimate/92sl10fl.html (viewed January 23, 2012).

U.S. Census Bureau. 1992. Annual Surveys of State and Local Government, www2.census.gov/govs/estimate/ (viewed September 14, 2010).

Wasylenko, Michael. 1997. Taxation and Economic Development: The State of the Economic Literature, New England Economic Review March/April, 37-52.

White, Michelle J. 1975. Suburban Zoning in Fragmented Metropolitan Areas, in Fiscal Zoning and Land Use Controls, E.S. Mills and W.E. Oates, eds., Lexington, MA: D. C. Heath, 31-100. 
Table 1A: Number of Florida Counties Imposing Local Sales Taxes

\begin{tabular}{|c|c|c|c|c|c|c|c|c|c|c|}
\hline \multirow{2}{*}{$\begin{array}{l}\text { Year } \\
1992\end{array}$} & \multicolumn{2}{|c|}{$\begin{array}{c}\text { All Local } \\
\text { Sales Taxes }\end{array}$} & \multicolumn{2}{|c|}{$\begin{array}{c}\text { Infrastructure or } \\
\text { Small County } \\
\text { Surtax } \\
\end{array}$} & \multicolumn{2}{|c|}{$\begin{array}{c}\text { School } \\
\text { Capital } \\
\text { Outlay Tax } \\
\end{array}$} & \multicolumn{2}{|c|}{$\begin{array}{l}\text { Indigent Care, } \\
\text { Trauma Center, } \\
\text { or Hospital Tax }\end{array}$} & \multicolumn{2}{|c|}{$\begin{array}{c}\text { Charter } \\
\text { County } \\
\text { Transit } \\
\text { System Tax }\end{array}$} \\
\hline & 35 & $(.87)$ & 32 & $(.91)$ & 0 & $(0)$ & 2 & $(.50)$ & 1 & $(.50)$ \\
\hline 1993 & 37 & $(.93)$ & 34 & $(.97)$ & 0 & $(0)$ & 2 & $(.50)$ & 1 & $(.50)$ \\
\hline 1994 & 42 & $(.94)$ & 39 & $(.97)$ & 0 & $(0)$ & 2 & $(.50)$ & 1 & $(.50)$ \\
\hline 1995 & 47 & $(.91)$ & 44 & $(.94)$ & 0 & $(0)$ & 2 & $(.50)$ & 1 & $(.50)$ \\
\hline 1996 & 50 & $(.96)$ & 46 & $(.98)$ & 3 & $(.42)$ & 2 & $(.50)$ & 1 & $(.50)$ \\
\hline 1997 & 51 & $(.95)$ & 47 & $(.97)$ & 4 & $(.44)$ & 2 & $(.50)$ & 1 & $(.50)$ \\
\hline 1998 & 50 & $(.98)$ & 46 & $(.97)$ & 7 & $(.45)$ & 2 & $(.38)$ & 1 & $(.50)$ \\
\hline 1999 & 52 & $(.95)$ & 46 & $(.96)$ & 8 & $(.50)$ & 2 & $(.38)$ & 1 & $(.50)$ \\
\hline 2000 & 50 & $(.97)$ & 44 & $(.98)$ & 8 & $(.50)$ & 2 & $(.38)$ & 1 & $(.50)$ \\
\hline 2001 & 50 & $(.97)$ & 45 & $(.96)$ & 8 & $(.50)$ & 2 & $(.41)$ & 1 & $(.50)$ \\
\hline 2002 & 51 & $(.97)$ & 45 & $(.97)$ & 9 & $(.50)$ & 2 & $(.50)$ & 1 & $(.50)$ \\
\hline 2003 & 54 & $(.97)$ & 46 & $(.96)$ & 13 & $(.50)$ & 2 & $(.50)$ & 2 & $(.50)$ \\
\hline 2004 & 54 & $(.96)$ & 45 & $(.97)$ & 13 & $(.50)$ & 2 & $(.50)$ & 2 & $(.50)$ \\
\hline 2005 & 58 & $(.94)$ & 45 & $(.97)$ & 16 & $(.50)$ & 4 & $(.44)$ & 2 & $(.50)$ \\
\hline 2006 & 58 & $(.94)$ & 46 & $(.96)$ & 16 & $(.50)$ & 4 & $(.44)$ & 2 & $(.50)$ \\
\hline
\end{tabular}

Notes: Figures in parentheses are the average local sales tax rate for counties that impose each local sales tax. Sources: State of Florida Department of Revenue (2010), and Florida Legislative Committee on Intergovernmental Relations (2009). 
Table 1B: Local Sales Tax Rate Changes in Florida, 1993-2006

\begin{tabular}{|c|c|c|c|c|c|}
\hline \multicolumn{7}{|c|}{ Total number of counties changing their tax rates } \\
\hline Year & $\begin{array}{c}\text { Aggregate } \\
\text { Local Sales } \\
\text { Tax Rate }\end{array}$ & $\begin{array}{c}\text { Infrastructure } \\
\text { Tax or Small } \\
\text { County Tax }\end{array}$ & $\begin{array}{c}\text { School } \\
\text { Capital } \\
\text { Outlay Tax }\end{array}$ & $\begin{array}{c}\text { Indigent Care, } \\
\text { Trauma Center, } \\
\text { or Hospital Tax }\end{array}$ & $\begin{array}{c}\text { Charter } \\
\text { County } \\
\text { Transit } \\
\text { System Tax }\end{array}$ \\
\hline 1993 & 9 & 9 & 0 & 0 & 0 \\
\hline 1994 & 7 & 7 & 0 & 0 & 0 \\
\hline 1995 & 9 & 9 & 0 & 0 & 0 \\
\hline 1996 & 8 & 6 & 3 & 0 & 0 \\
\hline 1997 & 4 & 2 & 2 & 0 & 0 \\
\hline 1998 & 6 & 2 & 4 & 1 & 0 \\
\hline 1999 & 5 & 4 & 2 & 0 & 0 \\
\hline 2000 & 2 & 2 & 0 & 0 & 0 \\
\hline 2001 & 3 & 2 & 0 & 1 & 0 \\
\hline 2002 & 5 & 3 & 1 & 1 & 0 \\
\hline 2003 & 7 & 4 & 4 & 0 & 0 \\
\hline 2004 & 3 & 1 & 2 & 0 & 0 \\
\hline 2005 & 6 & 2 & 3 & 2 & 0 \\
\hline 2006 & 1 & 1 & 0 & 0 & 0 \\
\hline
\end{tabular}

Sources: State of Florida Department of Revenue (2010), and Florida Legislative Committee on Intergovernmental Relations (2009). 
Table 2: Florida County Sales Tax Rates, 1992-2006

\begin{tabular}{|c|c|c|}
\hline County & 1992 rate & Changes \\
\hline Alachua & 0 & $1 \%$ in 2002,0 in $2003, .25 \%$ in 2005 \\
\hline Baker & 0 & $1 \%$ in 1994 \\
\hline Bay & $0.50 \%$ & $1 \%$ in $1994, .5 \%$ in $1995,1 \%$ in $1998, .5 \%$ in 2004 \\
\hline Bradford & $1 \%$ & \\
\hline Brevard & 0 & \\
\hline Broward & 0 & \\
\hline Calhoun & 0 & $1 \%$ in 1993 \\
\hline Charlotte & 0 & $.75 \%$ in $1995,1 \%$ in 2006 \\
\hline Citrus & 0 & \\
\hline Clay & $1 \%$ & \\
\hline Collier & 0 & \\
\hline Columbia & 0 & $1 \%$ in 1994 \\
\hline Desoto & $1 \%$ & \\
\hline Dixie & $1 \%$ & \\
\hline Duval & $0.50 \%$ & $1 \%$ in 2001 \\
\hline Escambia & $0.58 \%$ & $1 \%$ in $1993,1.5 \%$ in 2000 \\
\hline Flagler & $1 \%$ & \\
\hline Franklin & 0 & \\
\hline Gadsden & $1 \%$ & \\
\hline Gilchrist & $0.25 \%$ & $1 \%$ in 1993 \\
\hline Glades & $1 \%$ & \\
\hline Gulf & 0 & $.25 \%$ in $1997, .5 \%$ in $1998,1 \%$ in 2006 \\
\hline Hamilton & $1 \%$ & \\
\hline Hardee & $1 \%$ & \\
\hline Hendry & $1 \%$ & \\
\hline Hernando & 0 & $.5 \%$ in 1999,0 in $2004, .5 \%$ in 2005 \\
\hline Highlands & $1 \%$ & \\
\hline Hillsborough & $0.50 \%$ & $.94 \%$ in $1997, .75 \%$ in $1998, .81 \%$ in $2001,1 \%$ in 2002 \\
\hline Holmes & 0 & $1 \%$ in 1995 \\
\hline Indian River & $1 \%$ & \\
\hline Jackson & $0.5 \%$ & 0 in $1993, .58 \%$ in $1995,1.25 \%$ in $1996,1.5 \%$ in 1997 \\
\hline Jefferson & $1 \%$ & \\
\hline Lafayette & $1 \%$ & \\
\hline Lake & $1 \%$ & \\
\hline Lee & 0 & \\
\hline Leon & $1 \%$ & $1.5 \%$ in 2003 \\
\hline Levy & $0.25 \%$ & $1 \%$ in 1993 \\
\hline Liberty & 0 & $1 \%$ in 1993 \\
\hline Madison & $1 \%$ & \\
\hline Manatee & $1 \%$ & 0 in $1993, .5 \%$ in $1994,1 \%$ in $1995, .5 \%$ in 1999,0 in $2000, .5$ in 2003 \\
\hline Marion & 0 & $1 \%$ in $2003, .5 \%$ in 2005 \\
\hline Martin & 0 & $.583 \%$ in $1996, .417 \%$ in 1997,0 in $1998,1 \%$ in 1999,0 in 2002 \\
\hline Miami-Dade & $0.50 \%$ & $1 \%$ in 2003 \\
\hline Monroe & $1 \%$ & $1.5 \%$ in 1996 \\
\hline Nassau & 0 & $.5 \%$ in 1994,0 in $1995,1 \%$ in 1996 \\
\hline Okaloosa & 0 & $.42 \%$ in $1995,1 \%$ in $1996, .58 \%$ in 1999,0 in 2000 \\
\hline Okeechobee & 0 & $.25 \%$ in $1995,1 \%$ in 1996 \\
\hline Orange & 0 & $.5 \%$ in 2003 \\
\hline Osceola & $1 \%$ & \\
\hline Palm Beach & 0 & $.5 \%$ in 2005 \\
\hline
\end{tabular}




\begin{tabular}{|l|c|l|}
\hline County & 1992 rate & \\
\hline Pasco & 0 & $1 \%$ in 2005 \\
\hline Pinellas & $1 \%$ & \\
\hline Polk & 0 & $.5 \%$ in $2004,1 \%$ in 2005 \\
\hline Putnam & 0 & $1 \%$ in 2003 \\
\hline Saint Johns & 0 & \\
\hline Saint Lucie & 0 & $.5 \%$ in 1996 \\
\hline Santa Rosa & 0 & $.33 \%$ in $1993,1 \%$ in $1994, .79 \%$ in $1998, .5 \%$ in 1999 \\
\hline Sarasota & $1 \%$ & \\
\hline Seminole & $1 \%$ & $.75 \%$ in $2001,1 \%$ in 2002 \\
\hline Sumter & $1 \%$ & \\
\hline Suwannee & $1 \%$ & \\
\hline Taylor & $1 \%$ & \\
\hline Union & 0 & $1 \%$ in 1993 \\
\hline Volusia & 0 & $.5 \%$ in 2002 \\
\hline Wakulla & $1 \%$ & \\
\hline Walton & 0 & $1 \%$ in 1995 \\
\hline Washington & 0 & $1 \%$ in 1994 \\
\hline
\end{tabular}

Sources: State of Florida Department of Revenue (various years). 
Table 3: Summary Statistics

\begin{tabular}{|l|c|c|c|c|}
\hline \multicolumn{5}{|c|}{ A. County-Level } \\
\hline Variable & Mean & Std. Dev. & Min. & Max. \\
\hline $\begin{array}{l}\text { Sales tax rate, local plus state, } \\
\text { current }\end{array}$ & 6.70 & 0.458 & 6.0 & 7.5 \\
\hline Sales tax rate, local plus state, lagged & 6.69 & 0.461 & 6.0 & 7.5 \\
\hline Neighboring sales tax rate, current & 6.65 & 0.301 & 5.69 & 7.27 \\
\hline $\begin{array}{l}\text { Neighboring local sales tax rate, } \\
\text { lagged }\end{array}$ & 6.64 & 0.305 & 5.66 & 7.27 \\
\hline Total retail employment & 22,670 & 38,744 & 81 & 240,868 \\
\hline Big box/anchor retail employment & 1,678 & 2,720 & 0 & 16,975 \\
\hline Manufacturing employment & 9,912 & 18,805 & 25 & 111,510 \\
\hline & 6.70 & 0.459 & 6.0 & 7.5 \\
\hline $\begin{array}{l}\text { Sales tax rate, local plus state, } \\
\text { current }\end{array}$ & 6.69 & 0.463 & 6.0 & 7.5 \\
\hline $\begin{array}{l}\text { Sales tax rate, local plus state, } \\
\text { lagged }\end{array}$ & 6.62 & 0.524 & 5.0 & 7.5 \\
\hline Neighboring sales tax rate, current & 6.61 & 0.526 & 5.0 & 7.5 \\
\hline Neighboring sales tax rate, lagged & 5,129 & 19,177 & 0 & 219,529 \\
\hline Total retail employment & 382 & 1,4382 & 0 & 14,928 \\
\hline Big box/anchor retail employment & 2,209 & 9,295 & 0 & 109,190 \\
\hline Manufacturing employment & & & & \\
\hline
\end{tabular}

Notes: In Panel A, there are 1,005 county-year observations (15 years of data for 67 counties) on the contemporaneous variables, and 938 county-year observations (14 years of data for 67 counties) on the lagged variables. In Panel B, there are 4,155 locality-year observations (15 years of data for border and interior regions of each county), and 3,878 locality-year observations on the lagged variables. Border regions extend one mile inward from county borders; their construction is explained in Section VII. 
Table 4A: Regression Results Explaining Total Retail Employment, County-Level Analysis

\begin{tabular}{|c|c|c|c|c|c|c|}
\hline \multirow{2}{*}{ Explanatory variables } & (1) & (1') & (2) & (2') & (3) & (3') \\
\hline & Unwgt. & Wgt. & Unwgt. & Wgt. & Unwgt. & Wgt. \\
\hline Sales tax rate, current & $\begin{array}{c}0.016 \\
(0.017)\end{array}$ & $\begin{array}{c}0.002 \\
(0.016)\end{array}$ & $\begin{array}{l}-0.014 \\
(0.015)\end{array}$ & $\begin{array}{l}-0.017 \\
(0.012)\end{array}$ & $\begin{array}{l}-0.013 \\
(0.020)\end{array}$ & $\begin{array}{l}-0.005 \\
(0.013)\end{array}$ \\
\hline Sales tax rate, lagged & - & - & $\begin{array}{c}0.030 \\
(0.021)\end{array}$ & $\begin{array}{c}0.019 \\
(0.013)\end{array}$ & $\begin{array}{c}0.028 \\
(0.021)\end{array}$ & $\begin{array}{c}0.014 \\
(0.012)\end{array}$ \\
\hline $\begin{array}{l}\text { Neighboring sales tax } \\
\text { rate, current }\end{array}$ & - & - & - & - & $\begin{array}{l}-0.010 \\
(0.056)\end{array}$ & $\begin{array}{c}-0.059 * * \\
(0.020)\end{array}$ \\
\hline $\begin{array}{l}\text { Neighboring sales tax } \\
\text { rate, lagged }\end{array}$ & - & - & - & & $\begin{array}{c}0.011 \\
(0.023)\end{array}$ & $\begin{array}{l}0.023^{*} \\
(0.014)\end{array}$ \\
\hline \multicolumn{3}{|c|}{$\begin{array}{l}\text { Effect of a unit increase in current plus lagged } \\
\text { sales tax rate }\end{array}$} & $\begin{array}{l}0.016 \\
(0.024)\end{array}$ & $\begin{array}{c}0.002 \\
(0.019)\end{array}$ & $\begin{array}{c}0.015 \\
(0.023)\end{array}$ & $\begin{array}{c}0.009 \\
(0.020)\end{array}$ \\
\hline $\mathrm{R}^{2}$ & 0.99 & 0.99 & 0.99 & 0.99 & 0.99 & 0.99 \\
\hline
\end{tabular}

The dependent variable is the log of total retail employment. The sample period covers 19922006. There are 1,005 observations for the contemporaneous specifications, and 938 observations for the specifications with lags. The sales tax rate variable is the sum of the local sales tax plus the 6\% general Florida sales tax, measured in units of 0-100. All specifications include county and year fixed effects, and county-time trend interactions. Standard errors are clustered at the county level. 1992 population levels are used as weights in the columns labeled "Wgt." ** indicates statistical significance at the $5 \%$ level, and * at the $10 \%$ level.

Table 4B: Regression Results Explaining Retail Employment at Big Box and Anchor Stores, County-Level Analysis

\begin{tabular}{|c|c|c|c|c|c|c|}
\hline \multirow[b]{2}{*}{ Explanatory variables } & $(1)$ & $\left(1^{\prime}\right)$ & (2) & $\left(2^{\prime}\right)$ & (3) & $\left(3^{\prime}\right)$ \\
\hline & Unwgt. & Wgt. & Unwgt. & Wgt. & Unwgt. & Wgt. \\
\hline Sales tax rate, current & $\begin{array}{l}0.208^{*} \\
(0.113)\end{array}$ & $\begin{array}{l}0.134 * * \\
(0.056)\end{array}$ & $\begin{array}{c}0.047 \\
(0.090)\end{array}$ & $\begin{array}{c}0.080 \\
(0.049)\end{array}$ & $\begin{array}{l}-0.004 \\
(0.177)\end{array}$ & $\begin{array}{c}0.074 \\
(0.053)\end{array}$ \\
\hline Sales tax rate, lagged & - & - & $\begin{array}{c}0.256 \\
(0.224)\end{array}$ & $\begin{array}{l}0.085^{*} \\
(0.044)\end{array}$ & $\begin{array}{c}0.313 \\
(0.233)\end{array}$ & $\begin{array}{c}0.076 \\
(0.048)\end{array}$ \\
\hline $\begin{array}{l}\text { Neighboring sales tax } \\
\text { rate, current }\end{array}$ & - & - & - & - & $\begin{array}{c}0.293 \\
(0.534)\end{array}$ & $\begin{array}{c}0.029 \\
(0.102)\end{array}$ \\
\hline $\begin{array}{l}\text { Neighboring sales tax } \\
\text { rate, lagged }\end{array}$ & - & - & - & - & $\begin{array}{l}-0.288 \\
(0.225)\end{array}$ & $\begin{array}{c}0.033 \\
(0.072)\end{array}$ \\
\hline \multicolumn{3}{|c|}{$\begin{array}{l}\text { Effect of a unit increase in current plus lagged } \\
\text { local sales tax rate }\end{array}$} & $\begin{array}{c}0.303 \\
(0.192)\end{array}$ & $\begin{array}{l}0.166^{* *} \\
(0.064)\end{array}$ & $\begin{array}{l}0.309^{* *} \\
(0.135)\end{array}$ & $\begin{array}{l}0.150^{* *} \\
(0.063)\end{array}$ \\
\hline $\mathrm{R}^{2}$ & 0.98 & 0.98 & 0.98 & 0.98 & 0.98 & 0.99 \\
\hline
\end{tabular}

The dependent variable is the log of the sum of big box and anchor store employment. See the text for a list of stores. All specifications include county and year fixed effects, and county-time trend interactions. Standard errors are clustered at the county level. 1992 population levels are used as weights in the columns labeled "Wgt." Other details from notes to Table 4A apply here. 
Table 4C: Regression Results Explaining Total Retail Employment Excluding Big Box and Anchor Store Retail Employment, County-Level Analysis

\begin{tabular}{|l|c|c|c|c|c|c|}
\hline \multirow{2}{*}{ Explanatory variables } & $(1)$ & $\left(1^{\prime}\right)$ & $(2)$ & $\left(2^{\prime}\right)$ & $(3)$ & $\left(3^{\prime}\right)$ \\
\cline { 2 - 7 } & Unwgt. & Wgt. & Unwgt. & Wgt. & Unwgt. & Wgt. \\
\hline Sales tax rate, current & -0.0006 & -0.008 & -0.022 & $-0.025^{* *}$ & -0.016 & -0.012 \\
& $(0.014)$ & $(0.014)$ & $(0.014)$ & $(0.011)$ & $(0.015)$ & $(0.011)$ \\
\hline Sales tax rate, lagged & - & - & 0.014 & 0.015 & 0.011 & 0.010 \\
& & & $(0.014)$ & $(0.014)$ & $(0.015)$ & $(0.012)$ \\
\hline $\begin{array}{l}\text { Neighboring sales tax } \\
\text { rate, current }\end{array}$ & - & - & - & - & -0.032 & $-0.064^{* *}$ \\
\hline $\begin{array}{l}\text { Neighboring sales tax } \\
\text { rate, lagged }\end{array}$ & - & - & - & - & 0.022 & $0.022^{*}$ \\
\hline $\begin{array}{l}\text { Effect of a unit increase in current plus lagged } \\
\text { sales tax rate }\end{array}$ & -0.008 & -0.010 & -0.005 & -0.002 \\
\hline $\mathrm{R}^{2}$ & 0.99 & 0.99 & 0.99 & 0.99 & 0.99 & 0.99 \\
\hline
\end{tabular}

The dependent variable is the log of total retail employment excluding big box and anchor store retail employment. All specifications include county and year fixed effects, and countytime trend interactions. Standard errors are clustered at the county level. 1992 population levels are used as weights in the columns labeled "Wgt." Other details from notes to Table 4A apply here.

Table 4D: Regression Results Explaining Manufacturing Employment, County-Level Analysis

\begin{tabular}{|c|c|c|c|c|c|c|c|c|}
\hline \multirow{2}{*}{$\begin{array}{l}\text { Explanatory } \\
\text { variables }\end{array}$} & (1) & $\left(1^{\prime}\right)$ & (2) & (2') & (3) & $\left(3^{\prime}\right)$ & (4) & (4') \\
\hline & Unwgt. & Wgt. & Unwgt. & Wgt. & Unwgt. & Wgt. & Unwgt. & Wgt. \\
\hline $\begin{array}{l}\text { Sales tax rate, } \\
\text { current }\end{array}$ & $\begin{array}{l}-0.037 \\
(0.041)\end{array}$ & $\begin{array}{l}-0.023 \\
(0.029)\end{array}$ & $\begin{array}{c}0.025 \\
(0.032)\end{array}$ & $\begin{array}{c}0.008 \\
(0.023)\end{array}$ & $\begin{array}{c}0.034 \\
(0.042)\end{array}$ & $\begin{array}{l}-0.003 \\
(0.025)\end{array}$ & - & - \\
\hline $\begin{array}{l}\text { Sales tax rate, } \\
\text { lagged }\end{array}$ & - & - & $\begin{array}{l}-0.084 * \\
(0.046)\end{array}$ & $\begin{array}{c}-0.051 * * \\
(0.024)\end{array}$ & $\begin{array}{c}-0.102^{* *} \\
(0.048)\end{array}$ & $\begin{array}{c}-0.068^{* *} \\
(0.026) \\
\end{array}$ & $\begin{array}{l}-0.089^{*} \\
(0.052)\end{array}$ & $\begin{array}{c}-0.070^{* *} \\
(0.033)\end{array}$ \\
\hline $\begin{array}{l}\text { Neighboring sales } \\
\text { tax rate, current }\end{array}$ & - & - & - & - & $\begin{array}{l}-0.060 \\
(0.111)\end{array}$ & $\begin{array}{c}0.043 \\
(0.041)\end{array}$ & $\begin{array}{l}-0.037 \\
(0.098)\end{array}$ & $\begin{array}{c}0.041 \\
(0.036)\end{array}$ \\
\hline $\begin{array}{l}\text { Neighboring sales } \\
\text { tax rate, lagged }\end{array}$ & - & - & - & - & $\begin{array}{c}0.081 \\
(0.079)\end{array}$ & $\begin{array}{c}0.065 \\
(0.045)\end{array}$ & $\begin{array}{c}0.075 \\
(0.082) \\
\end{array}$ & $\begin{array}{c}0.066 \\
(0.047)\end{array}$ \\
\hline \multicolumn{3}{|c|}{$\begin{array}{l}\text { Effect of a unit increase in current plus } \\
\text { lagged local sales tax rate }\end{array}$} & $\begin{array}{l}-0.059 \\
(0.058)\end{array}$ & $\begin{array}{l}-0.043 \\
(0.037)\end{array}$ & $\begin{array}{l}-0.068 \\
(0.068)\end{array}$ & $\begin{array}{l}-0.071^{*} \\
(0.042)\end{array}$ & - & - \\
\hline R-Squared & 0.99 & 0.99 & 0.99 & 0.99 & 0.99 & 0.99 & 0.99 & 0.99 \\
\hline
\end{tabular}

The dependent variable is the log of manufacturing employment. All specifications include county and year fixed effects, and county-time trend interactions. Standard errors are clustered at the county level. 1992 population levels are used as weights in the columns labeled "Wgt." Other details from notes to Table 4A apply here. 
Table 5: Regression Results Explaining Big Box and Anchor Store Retail Employment and Manufacturing Employment with Enterprise Zone Dummies, County-Level Analysis, 1996-2006

\begin{tabular}{|l|c|c|c|c|c|c|c|c|}
\hline & \multicolumn{3}{|c}{ Big box and anchor store retail } & \multicolumn{4}{c|}{ Manufacturing } \\
\hline \multirow{2}{*}{$\begin{array}{l}\text { Explanatory } \\
\text { variables }\end{array}$} & $(1)$ & $\left(1^{\prime}\right)$ & $(2)$ & $\left(2^{\prime}\right)$ & $(3)$ & $\left(3^{\prime}\right)$ & $(4)$ & $\left(4^{\prime}\right)$ \\
\hline & Unwgt. & Unwgt. & Wgt. & Wgt. & Unwgt. & Unwgt. & Wgt. & Wgt. \\
Sales tax rate, & 0.156 & 0.154 & 0.078 & 0.077 & - & - & - & - \\
current & $(0.099)$ & $(0.099)$ & $(0.052)$ & $(0.051)$ & & & & \\
\hline Sales tax rate, & 0.014 & 0.015 & -0.008 & -0.010 & -0.091 & -0.092 & -0.055 & -0.051 \\
lagged & $(0.052)$ & $(0.052)$ & $(0.037)$ & $(0.037)$ & $(0.057)$ & $(0.057)$ & $(0.0349)$ & $(0.033)$ \\
\hline Neighboring sales & -0.051 & -0.051 & -0.039 & -0.040 & -0.003 & -0.005 & -0.029 & -0.026 \\
tax rate, current & $(0.138)$ & $(0.139)$ & $(0.093)$ & $(0.093)$ & $(0.145)$ & $(0.144)$ & $(0.044)$ & $(0.045)$ \\
\hline Neighboring sales & -0.064 & -0.062 & -0.028 & -0.028 & -0.009 & -0.007 & 0.008 & 0.008 \\
tax rate, lagged & $(0.102)$ & $(0.100)$ & $(0.063)$ & $(0.063)$ & $(0.114)$ & $(0.114)$ & $(0.056)$ & $(0.056)$ \\
\hline Enterprise zone & - & 0.048 & - & -0.030 & - & 0.042 & - & $0.034^{* *}$ \\
& & $(0.150)$ & & $(0.034)$ & & $(0.036)$ & & $(0.014)$ \\
\hline $\begin{array}{l}\text { Effect of a unit } \\
\text { increase in current } \\
\text { plus lagged local }\end{array}$ & & & & & & & & \\
sales tax rate & $0.171^{*}$ & 0.169 & 0.071 & 0.066 & & & & \\
\hline
\end{tabular}

The columns without primes report specifications like those in Tables 4B and 4D, excluding the enterprise zone control, for the subperiod for which enterprise zone information is available, accounting for the inclusion of the lagged sales tax variable (1996-2006). The columns with primes include the enterprise zone control, which is equal to one if there was an enterprise zone in effect in the county and year. There are 737 observations. All specifications include county and year fixed effects, and county-time trend interactions. Standard errors are clustered at the county level. 1992 population levels are used as weights in the columns labeled "Wgt." Other details from notes to Table 4A apply here. 
Table 6: Regression Results Explaining Changes in Big Box and Anchor Store Retail Employment and Manufacturing Employment, First Difference and Variable Lag Specifications

\begin{tabular}{|c|c|c|c|c|c|c|c|c|}
\hline & \multicolumn{4}{|c|}{ Retail big box and anchor stores } & \multicolumn{4}{|c|}{ Manufacturing } \\
\hline & \multicolumn{2}{|c|}{$\begin{array}{c}\text { One-year first } \\
\text { differences }\end{array}$} & \multicolumn{2}{|c|}{$\begin{array}{c}\text { Two-year first } \\
\text { differences }\end{array}$} & \multicolumn{2}{|c|}{ One-year first differences } & \multicolumn{2}{|c|}{$\begin{array}{c}\text { Two-year first } \\
\text { differences }\end{array}$} \\
\hline \multirow{3}{*}{$\begin{array}{l}\text { Explanatory variables, first differences } \\
\text { A. Specification with current and lagged sales tax } \\
\text { rates }\end{array}$} & $(1)$ & $\left(1^{\prime}\right)$ & $(2)$ & $(2 ’)$ & $(3)$ & $\left(3^{\prime}\right)$ & $(4)$ & $(4 ')$ \\
\hline & Unwgt. & Wgt. & Unwgt. & Wgt. & Unwgt. & Wgt. & Unwgt. & Wgt. \\
\hline & & & & & & & & \\
\hline Sales tax rate, current & $\begin{array}{c}0.053 \\
(0.081)\end{array}$ & $\begin{array}{c}0.061 \\
(0.043)\end{array}$ & $\begin{array}{c}0.082 \\
(0.115)\end{array}$ & $\begin{array}{l}0.130^{* *} \\
(0.050)\end{array}$ & - & - & - & - \\
\hline Sales tax rate, lagged two years & $\begin{array}{c}0.011 \\
(0.060)\end{array}$ & $\begin{array}{c}0.025 \\
(0.031)\end{array}$ & $\begin{array}{c}0.176 \\
(0.109)\end{array}$ & $\begin{array}{l}0.109 * * \\
(0.044)\end{array}$ & $\begin{array}{l}-0.034 \\
(0.027)\end{array}$ & $\begin{array}{c}-0.001 \\
(0.015) \\
\end{array}$ & $\begin{array}{l}-0.052 \\
(0.033)\end{array}$ & $\begin{array}{l}-0.036^{*} \\
(0.022)\end{array}$ \\
\hline Sales tax rate, lagged three years & - & - & - & - & $\begin{array}{l}-0.047^{*} \\
(0.026) \\
\end{array}$ & $\begin{array}{l}-0.027^{*} \\
(0.017) \\
\end{array}$ & $\begin{array}{l}-0.051^{*} \\
(0.031) \\
\end{array}$ & $\begin{array}{l}-0.001 \\
(0.027) \\
\end{array}$ \\
\hline Sum of sales tax coefficients (cumulative effect) & $\begin{array}{c}0.306 \\
(0.269) \\
\end{array}$ & $\begin{array}{l}0.116^{*} \\
(0.067) \\
\end{array}$ & $\begin{array}{l}0.331^{*} \\
(0.169) \\
\end{array}$ & $\begin{array}{l}0.209^{* *} \\
(0.068) \\
\end{array}$ & $\begin{array}{c}-0.139 * * \\
(0.065) \\
\end{array}$ & $\begin{array}{c}-0.077 * * \\
(0.035) \\
\end{array}$ & $\begin{array}{c}-0.159 * * \\
(0.071) \\
\end{array}$ & $\begin{array}{l}-0.059^{*} \\
(0.034) \\
\end{array}$ \\
\hline $\mathrm{R}^{2}$ & 0.076 & 0.102 & 0.127 & 0.167 & 0.088 & 0.143 & 0.164 & 0.232 \\
\hline $\mathrm{N}$ & 804 & 804 & 737 & 737 & 737 & 737 & 670 & 670 \\
\hline Sales tax rate, one- or two- year lead & $\begin{array}{l}0.121^{* *} \\
(0.060)\end{array}$ & $\begin{array}{l}0.079 * * \\
(0.031) \\
\end{array}$ & $\begin{array}{c}0.174 \\
(0.119) \\
\end{array}$ & $\begin{array}{c}0.059 \\
(0.043) \\
\end{array}$ & $\begin{array}{l}-0.025 \\
(0.027) \\
\end{array}$ & $\begin{array}{l}-0.040^{*} \\
(0.024) \\
\end{array}$ & $\begin{array}{l}-0.036 \\
(0.031) \\
\end{array}$ & $\begin{array}{c}-0.034 \\
(0.028) \\
\end{array}$ \\
\hline $\begin{array}{l}\text { Sum of current and lagged sales tax coefficients, } \\
\text { specification including lead }\end{array}$ & $\begin{array}{c}0.369 \\
(0.295)\end{array}$ & $\begin{array}{l}0.176^{* *} \\
(0.068)\end{array}$ & $\begin{array}{l}0.304^{*} \\
(0.167)\end{array}$ & $\begin{array}{l}0.239^{* *} \\
(0.074)\end{array}$ & $\begin{array}{c}-0.142 * * \\
(0.063)\end{array}$ & $\begin{array}{c}-0.094 * * \\
(0.037)\end{array}$ & $\begin{array}{c}-0.188^{* *} \\
(0.074)\end{array}$ & $\begin{array}{r}-0.105^{* *} \\
(0.044)\end{array}$ \\
\hline $\begin{array}{l}\text { Sum of lead, current, and lagged sales tax } \\
\text { coefficients, specification including lead }\end{array}$ & $\begin{array}{c}0.489 \\
(0.306)\end{array}$ & $\begin{array}{r}0.255^{* *} \\
(0.079)\end{array}$ & $\begin{array}{l}0.478^{*} \\
(0.249)\end{array}$ & $\begin{array}{c}0.298^{* *} \\
(0.090)\end{array}$ & $\begin{array}{c}-0.166^{* *} \\
(0.070)\end{array}$ & $\begin{array}{c}-0.134 * * \\
(0.051) \\
\end{array}$ & $\begin{array}{c}-0.224 * * \\
(0.086)\end{array}$ & $\begin{array}{r}-0.139 * * \\
(0.062)\end{array}$ \\
\hline $\begin{array}{l}\text { Sum of current and lagged sales tax coefficients, } \\
\text { specification excluding lead }\end{array}$ & $\begin{array}{c}0.335 \\
(0.294) \\
\end{array}$ & $\begin{array}{l}0.146^{* *} \\
(0.071)\end{array}$ & $\begin{array}{l}0.351^{*} \\
(0.185) \\
\end{array}$ & $\begin{array}{c}0.254^{* *} \\
(0.076)\end{array}$ & $\begin{array}{c}-0.136^{* *} \\
(0.063) \\
\end{array}$ & $\begin{array}{c}-0.078^{* *} \\
(0.034) \\
\end{array}$ & $\begin{array}{c}-0.173 * * \\
(0.074) \\
\end{array}$ & $\begin{array}{r}-0.083 * * \\
(0.039) \\
\end{array}$ \\
\hline $\mathrm{N}$ & 737 & 737 & 670 & 670 & 670 & 670 & 603 & 603 \\
\hline
\end{tabular}

Aside from the additional lags and using short first differences rather than within-group estimation, notes from Tables, 4A, 4B, and 4D apply here. The first

differences of the explanatory variables are computed over one year or two years, as indicated in the column heading. All specifications include county and year fixed effects; the county-trend interactions drop out because of the differencing. In Panel B, the one-year or two-year first-differenced lead is included, corresponding to the specification. Standard errors are clustered at the county level. 1992 population levels are used as weights in the columns labeled "Wgt." 
Table 7: Regression Results Explaining Changes in Retail Employment at New Big Box and Anchor Stores, County-Level Analysis

\begin{tabular}{|l|c|c|c|c|}
\hline & \multicolumn{4}{|c|}{ Retail big box and anchor stores } \\
\hline & \multicolumn{2}{|c|}{$\begin{array}{c}\text { Change in employment } \\
\text { at new stores, } \\
\text { one-year window }\end{array}$} & $\begin{array}{c}\text { Change in employment } \\
\text { at new stores, } \\
\text { two-year window }\end{array}$ \\
\hline $\begin{array}{l}\text { Explanatory } \\
\text { variables, first } \\
\text { differences }\end{array}$ & $(1)$ & $\left(1^{\prime}\right)$ & $(2)$ & $\left(2^{\prime}\right)$ \\
\cline { 2 - 5 } & Unwgt. & Wgt. & Unwgt. & Wgt. \\
\hline Sales tax rate, current & $\begin{array}{c}56.05 \\
(34.56)\end{array}$ & $\begin{array}{c}78.35 \\
(72.10)\end{array}$ & $\begin{array}{c}46.82 \\
(29.58)\end{array}$ & $\begin{array}{c}74.58 \\
(76.38)\end{array}$ \\
\hline $\begin{array}{l}\text { Sales tax rate, lagged } \\
\text { one year }\end{array}$ & $\begin{array}{c}59.16^{* *} \\
(28.97)\end{array}$ & $\begin{array}{c}84.94 \\
(58.62)\end{array}$ & $\begin{array}{c}10.41 \\
(24.41)\end{array}$ & $\begin{array}{c}26.44 \\
(81.76)\end{array}$ \\
\hline $\begin{array}{l}\text { Sales tax rate, lagged } \\
\text { two years }\end{array}$ & $\begin{array}{c}22.52 \\
(19.37)\end{array}$ & $\begin{array}{c}-41.46 \\
(131.73)\end{array}$ & $\begin{array}{c}43.32^{* *} \\
(17.97)\end{array}$ & $\begin{array}{c}62.50 \\
(66.04)\end{array}$ \\
\hline $\begin{array}{l}\text { Sum of sales tax } \\
\text { coefficients } \\
\text { (cumulative effect) }\end{array}$ & $\begin{array}{c}137.73^{* *} \\
(52.86)\end{array}$ & $\begin{array}{c}121.83 \\
(129.31)\end{array}$ & $\begin{array}{c}100.55^{* *} \\
(39.37)\end{array}$ & $\begin{array}{c}163.53 * \\
(89.86)\end{array}$ \\
\hline $\mathrm{R}^{2}$ & 0.535 & 0.580 & 0.517 & 0.533 \\
\hline $\mathrm{N}$ & 804 & 804 & 737 & 737 \\
\hline
\end{tabular}

The dependent variable is employment created by births or move-ins of stores. For the one-year window, births or move-ins are identified as stores that had zero employment in the county in period $t-1$, but positive employment in the county in period $t$. The change in employment is then employment in period $t$, which measures the employment created by the birth or move-in. (Almost all of the variation is from births.) For the two-year window, new establishments are identified between periods $t-2$ and $t$. The unweighted means are 90.92 for the one-year window, and 87.35 for the two-year window. The first differences of the explanatory variables are computed over one year in columns (1) and (1') and over two years in columns (2) and (2'). All specifications include county and year fixed effects; the county-trend interactions drop out because of the differencing. Standard errors are clustered at the county level. 1992 population levels are used as weights in the columns labeled "Wgt." Notes from Tables 4A, $4 \mathrm{~B}, 4 \mathrm{D}$, and 6 apply here. 
Table 8A: Regression Results Explaining Total Retail Employment, Border-Interior Analysis

\begin{tabular}{|c|c|c|c|c|c|c|}
\hline Explanatory variables & (1) & (2) & (3) & (4) & (5) & (6) \\
\hline Sales tax rate, current & $\begin{array}{c}-0.032 \\
(0.049)\end{array}$ & $\begin{array}{l}-0.046 \\
(0.047)\end{array}$ & $\begin{array}{l}-0.037 \\
(0.056)\end{array}$ & $\begin{array}{l}0.020 \\
(0.077)\end{array}$ & $\begin{array}{l}-0.050 \\
(0.061)\end{array}$ & $\begin{array}{c}-0.021 \\
(0.092)\end{array}$ \\
\hline Sales tax rate, lagged & - & $\begin{array}{c}0.028 \\
(0.047)\end{array}$ & $\begin{array}{c}0.038 \\
(0.057)\end{array}$ & - & $\begin{array}{c}0.045 \\
(0.066)\end{array}$ & $\begin{array}{c}0.073 \\
(0.095)\end{array}$ \\
\hline $\begin{array}{l}\text { Sales tax rate, current, } x \text { border } \\
\text { dummy }\end{array}$ & - & - & - & $\begin{array}{l}-0.067 \\
(0.092)\end{array}$ & $\begin{array}{c}0.005 \\
(0.078)\end{array}$ & $\begin{array}{l}-0.019 \\
(0.088)\end{array}$ \\
\hline $\begin{array}{l}\text { Sales tax rate, lagged, } x \text { border } \\
\text { dummy }\end{array}$ & - & - & - & - & $\begin{array}{l}-0.023 \\
(0.084)\end{array}$ & $\begin{array}{l}-0.042 \\
(0.095)\end{array}$ \\
\hline Neighboring sales tax rate, current & - & - & $\begin{array}{l}-0.027 \\
(0.060)\end{array}$ & - & - & $\begin{array}{l}-0.030 \\
(0.066)\end{array}$ \\
\hline Neighboring sales tax rate, lagged & - & - & $\begin{array}{l}-0.026 \\
(0.060)\end{array}$ & - & - & $\begin{array}{l}-0.033 \\
(0.066)\end{array}$ \\
\hline \multicolumn{2}{|c|}{$\begin{array}{l}\text { Effect of a unit increase in current plus } \\
\text { lagged sales tax rate (in columns (2') and } \\
\left(3^{\prime}\right) \text {, results are for interior regions) }\end{array}$} & $\begin{array}{l}-0.018 \\
(0.070)\end{array}$ & $\begin{array}{c}0.001 \\
(0.084)\end{array}$ & - & $\begin{array}{l}-0.005 \\
(0.096)\end{array}$ & $\begin{array}{c}0.052 \\
(0.133)\end{array}$ \\
\hline \multicolumn{4}{|c|}{$\begin{array}{l}\text { Effect of a unit increase in current sales tax rate on employment in } \\
\text { border regions (main effect plus interaction) }\end{array}$} & $\begin{array}{l}-0.047 \\
(0.057)\end{array}$ & - & - \\
\hline \multicolumn{5}{|c|}{$\begin{array}{l}\text { Effect of a unit increase in current plus lagged sales tax rate on employment in } \\
\text { border regions (main effects plus interactions) }\end{array}$} & $\begin{array}{c}-0.022 \\
(0.080)\end{array}$ & $\begin{array}{l}-0.009 \\
(0.086)\end{array}$ \\
\hline \multicolumn{5}{|c|}{$\begin{array}{l}\text { Difference in effect of current plus lagged sales tax rate between border and } \\
\text { interior regions (sum of border interactions) }\end{array}$} & $\begin{array}{l}-0.017 \\
(0.111)\end{array}$ & $\begin{array}{l}-0.061 \\
(0.122)\end{array}$ \\
\hline $\mathrm{R}^{2}$ & 0.99 & 0.99 & 0.99 & 0.99 & 0.99 & 0.99 \\
\hline
\end{tabular}

The dependent variable is the $\log$ of total retail employment. There are 4,155 observations for the contemporaneous specifications, and 3,878 observations for the specifications with lags. The sales tax rate variable is the sum of the local sales tax plus the $6 \%$ general Florida sales tax, measured in units of $0-100$. The classification of border and interior regions is based on 1-mile border zones. All regressions include fixed effects for each sub-county area (each unique border area and county interior), year fixed effects, and county-time trend interactions. Standard errors are clustered at the sub-county region level. Estimates are not weighted. 
Table 8B: Regression Results Explaining Big Box and Anchor Store Retail Employment, Border-Interior Analysis

\begin{tabular}{|c|c|c|c|c|c|c|}
\hline Explanatory variables & (1) & $(2)$ & (3) & (4) & $(5)$ & $(6)$ \\
\hline Sales tax rate, current & $\begin{array}{l}-0.022 \\
(0.058)\end{array}$ & $\begin{array}{l}-0.031 \\
(0.042)\end{array}$ & $\begin{array}{l}-0.025 \\
(0.037)\end{array}$ & $\begin{array}{l}0.405^{* *} \\
(0.179)\end{array}$ & $\begin{array}{l}-0.017 \\
(0.150)\end{array}$ & $\begin{array}{c}0.011 \\
(0.153)\end{array}$ \\
\hline Sales tax rate, lagged & - & $\begin{array}{l}-0.006 \\
(0.070)\end{array}$ & $\begin{array}{l}-0.018 \\
(0.064)\end{array}$ & - & $\begin{array}{c}0.419 \\
(0.261)\end{array}$ & $\begin{array}{l}0.472 * \\
(0.270)\end{array}$ \\
\hline $\begin{array}{l}\text { Sales tax rate, current, } \mathrm{x} \text { border } \\
\text { dummy }\end{array}$ & - & - & - & $\begin{array}{c}-0.556^{* *} \\
(0.189) \\
\end{array}$ & $\begin{array}{l}-0.015 \\
(0.164) \\
\end{array}$ & $\begin{array}{l}-0.039 \\
(0.168) \\
\end{array}$ \\
\hline $\begin{array}{l}\text { Sales tax rate, lagged, } x \text { border } \\
\text { dummy }\end{array}$ & - & - & - & - & $\begin{array}{c}-0.554 * * \\
(0.269)\end{array}$ & $\begin{array}{c}-0.594 * * \\
(0.275)\end{array}$ \\
\hline Neighboring sales tax rate, current & - & - & $\begin{array}{l}-0.029 \\
(0.053)\end{array}$ & - & - & $\begin{array}{l}-0.029 \\
(0.047)\end{array}$ \\
\hline Neighboring sales tax rate, lagged & - & - & $\begin{array}{c}0.041 \\
(0.062)\end{array}$ & - & - & $\begin{array}{l}-0.060 \\
(0.054)\end{array}$ \\
\hline \multicolumn{2}{|c|}{$\begin{array}{l}\text { Effect of a unit increase in current plus } \\
\text { lagged sales tax rate (interior in columns (2') } \\
\text { and (3')) }\end{array}$} & $\begin{array}{l}-0.037 \\
(0.080)\end{array}$ & $\begin{array}{l}-0.042 \\
(0.078)\end{array}$ & - & $\begin{array}{l}0.403^{*} \\
(0.226)\end{array}$ & $\begin{array}{l}0.483^{* *} \\
(0.240)\end{array}$ \\
\hline \multicolumn{4}{|c|}{$\begin{array}{l}\text { Effect of a unit increase in current sales tax rate on employment in } \\
\text { border regions (main effect plus interaction) }\end{array}$} & $\begin{array}{c}-0.150^{* *} \\
(0.056)\end{array}$ & - & - \\
\hline \multicolumn{5}{|c|}{$\begin{array}{l}\text { Effect of a unit increase in current plus lagged sales tax rate on employment in } \\
\text { border regions (main effects plus interactions) }\end{array}$} & $\begin{array}{c}-0.167 * * \\
(0.070)\end{array}$ & $\begin{array}{c}-0.148^{* *} \\
(0.069)\end{array}$ \\
\hline \multicolumn{5}{|c|}{$\begin{array}{l}\text { Difference in effect of current plus lagged sales tax rate between border and } \\
\text { interior regions (sum of border interactions) }\end{array}$} & $\begin{array}{l}-0.569^{* *} \\
(0.226)\end{array}$ & $\begin{array}{c}-0.631 * * \\
(0.237)\end{array}$ \\
\hline $\mathrm{R}^{2}$ & 0.96 & 0.96 & 0.96 & 0.96 & 0.96 & 0.96 \\
\hline
\end{tabular}

The dependent variable is the log of the sum of big box and anchor store retail employment. All regressions include fixed effects for each sub-county area (each unique border area and county interior), year fixed effects, and county-time trend interactions. Standard errors are clustered at the sub-county region level. Estimates are not weighted. Other details from notes to Table 8A apply here. 
Table 8C: Regression Results Explaining Manufacturing Employment, Border-Interior Analysis

\begin{tabular}{|c|c|c|c|c|c|c|}
\hline Explanatory variables & (1) & (2) & (3) & (4) & $(5)$ & (6) \\
\hline Sales tax rate, current & $\begin{array}{c}0.074 \\
(0.076)\end{array}$ & $\begin{array}{c}0.080 \\
(0.075)\end{array}$ & $\begin{array}{c}0.066 \\
(0.080)\end{array}$ & $\begin{array}{l}-0.185 \\
(0.123)\end{array}$ & $\begin{array}{l}-0.162 * \\
(0.097)\end{array}$ & $\begin{array}{c}-0.278 * * \\
(0.133)\end{array}$ \\
\hline Sales tax rate, lagged & - & $\begin{array}{l}-0.027 \\
(0.063)\end{array}$ & $\begin{array}{l}-0.029 \\
(0.071)\end{array}$ & - & $\begin{array}{l}-0.090 \\
(0.107)\end{array}$ & $\begin{array}{l}-0.091 \\
(0.145)\end{array}$ \\
\hline $\begin{array}{l}\text { Sales tax rate, current, } \mathrm{x} \text { border } \\
\text { dummy }\end{array}$ & - & - & - & $\begin{array}{c}0.337 * * \\
(0.157)\end{array}$ & $\begin{array}{l}0.312^{* *} \\
(0.131)\end{array}$ & $\begin{array}{l}0.417^{* *} \\
(0.161)\end{array}$ \\
\hline $\begin{array}{l}\text { Sales tax rate, lagged, } x \text { border } \\
\text { dummy }\end{array}$ & - & - & - & - & $\begin{array}{c}0.084 \\
(0.137)\end{array}$ & $\begin{array}{c}0.070 \\
(0.164)\end{array}$ \\
\hline Neighboring sales tax rate, current & - & - & $\begin{array}{c}0.050 \\
(0.104)\end{array}$ & - & - & $\begin{array}{c}0.119 \\
(0.117)\end{array}$ \\
\hline Neighboring sales tax rate, lagged & - & - & $\begin{array}{l}-0.003 \\
(0.064)\end{array}$ & - & - & $\begin{array}{c}0.007 \\
(0.074)\end{array}$ \\
\hline \multicolumn{2}{|c|}{$\begin{array}{l}\text { Effect of a unit increase in current plus } \\
\text { lagged sales tax rate (interior in columns (2') } \\
\text { and (3')) }\end{array}$} & $\begin{array}{c}0.053 \\
(0.107)\end{array}$ & $\begin{array}{c}0.037 \\
(0.118)\end{array}$ & - & $\begin{array}{l}-0.253 \\
(0.154)\end{array}$ & $\begin{array}{c}-0.370^{* *} \\
(0.174)\end{array}$ \\
\hline \multicolumn{4}{|c|}{$\begin{array}{l}\text { Effect of a unit increase in current sales tax rate on employment in } \\
\text { border regions (main effect plus interaction) }\end{array}$} & $\begin{array}{c}0.151 \\
(0.094)\end{array}$ & - & - \\
\hline \multicolumn{5}{|c|}{$\begin{array}{l}\text { Effect of a unit increase in current plus lagged sales tax rate on employment in } \\
\text { border regions (main effects plus interactions) }\end{array}$} & $\begin{array}{c}0.143 \\
(0.126)\end{array}$ & $\begin{array}{c}0.118 \\
(0.131)\end{array}$ \\
\hline \multicolumn{5}{|c|}{$\begin{array}{l}\text { Difference in effect of current plus lagged sales tax rate between border and } \\
\text { interior regions (sum of border interactions) }\end{array}$} & $\begin{array}{c}0.400^{* *} \\
(0.189)\end{array}$ & $\begin{aligned} 0.487 * * \\
(0.197)\end{aligned}$ \\
\hline $\mathrm{R}^{2}$ & 0.97 & 0.97 & 0.97 & 0.97 & 0.97 & 0.97 \\
\hline
\end{tabular}

The dependent variable is the log of manufacturing employment. All regressions include fixed effects for each sub-county area (each unique border area and county interior), year fixed effects, and county-time trend interactions. Standard errors are clustered at the sub-county region level. Estimates are not weighted. Other details from notes to Table 8A apply here. 